Review

\title{
Employer Rights and Legal Defenses to OSHA Citations
}

\author{
${ }^{1}$ Thomas Oriet and ${ }^{2}$ Dr. Leo Oriet \\ ${ }^{1}$ Michigan State University College of Law, USA \\ ${ }^{2}$ Mechanical Engineering, University of Windsor, Canada
}

\section{Article history}

Received: 27-05-2018

Revised: 08-06-2018

Accepted: 07-08-2018

Corresponding Author:

Leo Oriet

Mechanical Engineering,

University of Windsor, Canada

Email: lporiet@uwindsor.ca

\begin{abstract}
Congress placed a statutory duty on the employer and employee to be safe in the workplace, but the courts do not reciprocate this duty onto employees. ${ }^{1}$ With plant managers understandably unaware of their rights, ${ }^{2}$ and with governmental tactics to obtain consent for administrative ease, ${ }^{3}$ a company's threat to litigation may derive from its ignorance of the law. This paper aims to educate employers of their rights and counter-arguments to Secretary of Labor ("Secretary") litigation as they seek independent legal counsel.
\end{abstract}

An employer can deny entry of an Occupational Health and Safety Administration ("OSHA") inspector lacking a warrant unless the business is in a pervasively regulated industry. The employer may ask for a copy of the warrant and the basis for the warrant and the OSHA inspector must articulate the scope and purpose of the search. An employer may request counsel to accompany the OSHA inspector during the investigation. Upon completion of the inspection, the Secretary or OSHA must issue a citation within six-months. In other words, the date of discovering a violation or when the alleged violation occurred starts the six-month statute of the limitations for a valid citation to be issued. The employer must appeal by notifying the Secretary within 15 business days after receipt of the citation. The Secretary of Labor always bears the initial burden of proving every element of an Occupational Safety and Health Act ("OSH Act") violation that resulted from the employer's alleged failed compliance.

An employer may raise the Multi-Employer Doctrine to argue it was an employee from another employer that created and controlled the hazard inducing incident. The employer must prove:

"(1) it did not create the violative condition to which its employees were exposed;

(2) it did not control the violative condition, so that it could not itself have performed the action necessary to abate the condition as required by the standard; and

(3) it took all reasonable alternative measures to protect its employees from the violative condition." ${ }^{4}$

\footnotetext{
${ }^{1}$ See, Atlantic \& Gulf Stevedores, Inc. v. OSHRC, 534 F.2d 541, 553 (3d Cir. 1976) ("Congress did not intend to confer on the Secretary or the Commission the power to sanction employees. Sections $2(\mathrm{~b})(2)$ and $5(\mathrm{~b})$ cannot be read apart from the detailed scheme of enforcement. . . It seems clear that this enforcement scheme is directed only against employers.").

${ }^{2}$ See, Camara v. Mun. Ct. of City and County of San Francisco, 387 U.S. 523, 539 (1967) ("Most citizens allow inspections of their property without a warrant").

${ }^{3}$ See, Fred Wilson Drilling Co., Inc., 6 O.S.H. Cas. (BNA) 1942 (A.L.J. Aug. 2, 1978).

${ }^{4}$ Wayne J. Griffin Electric, Inc., 26 BNA OSHC 1786 (No. 15-0858, 2017) (quoting Rockwell Int'l Corp., 17 BNA OSHC 1801, 1808 (No. 93-45, 1996)).
} 
An employer may argue that the OSH Act compliance is infeasible by demonstrating:

"(1) that compliance with a particular standard either is impossible or will render performance of the work impossible; and

(2) that the employer undertook alternative steps to protect its workers or that no such steps were available."

To rebut the presumption that the employer bears full responsibility for workplace safety, an employee's isolated and unforeseen misconduct may be held against the employee using the Unpreventable Employee Misconduct Defense. The employer shall need to prove:

"(1) it established work rules or policies designed to prevent the violation;

(2) it has adequately communicated these rules to its employees;

(3) it has taken steps to discover violations of the work rules; and

(4) it has effectively enforced these work rules when violations have been discovered."

An employer can seek a variance proceeding that allows OSHA to preapprove the alternative safety measure before being issued a citation. However, if the alternative private-sector created safety measure appears unable to provide equivalent safety protection as the OSHA standard, then the employer risks receiving a citation after OSHA makes a final determination. The employer relinquishes the option of arguing the Greater Hazard Defense upon requesting a variance proceeding. The Greater Hazard Defense requires the employer to prove:

(1) compliance with OSHA standards or guidance would result in a greater hazard to employees, which the standard was designed to prevent, than would noncompliance;

(2) the employer took reasonable alternative protective measures, or there are no alternative means of employee protection; and

(3) a variance was unavailable or applying for a variance would have been inappropriate. ${ }^{7}$

The employer may seek a variance or risk losing the Greater Hazard Defense. An unjustified failure to seek a variance proceeding shall preclude the Greater Hazard Defense; thus, there is no defense when the employer failed to ask for one when appropriate. If an employer can show it could not seek a variance proceeding due to a statue or procedure, then the defense may be raised. An employer should do everything it can to reduce its employees' exposure to reasonably foreseeable hazards to reduce the gravity ${ }^{8}$ of the citation charges, even if the OSHA standard is economically or technically infeasible.

Keywords: Fourth Amendment, OSHA Inspections, Multi-Employer Doctrine, Appeal, General Duty Clause, Unpreventable Employee Misconduct, Greater Hazard Defense, Infeasibility, Impossibility Defense, Burden of Proof, Work Rule, Statute of Limitations

\footnotetext{
${ }^{5}$ Harry C. Crooker \& Sons, Inc. v. OSHRC, 537 F.3d 79, 82 (1st Cir. 2008) (emphasis added); E \& R Erectors, Inc. v. Sec'y of Labor, 107 F.3d 157, 163 (3rd Cir. 1997). ${ }^{6}$ Danis Shook Joint Venture XXV, 19 O.S.H. Cas. (BNA) 1497 (O.S.H.R.C. Aug. 2, 2001) (quoting Gem Indus., Inc., 17 O.S.H. Cas. (BNA) 1861 (O.S.H.R.C. Dec. 6, 1996)) (emphasis added). See, OSHA Field Op Man. Sec VI(B)(1)(b), Ch. 5 (D.O.L.).

${ }^{7}$ OSHA Field Op Man. Sec VI, Ch. 5, S B(3) (D.O.L.)(emphasis added); See, Dole v. Williams Enter. Inc., 876 F.2d 186 (quoting Lauhoff Grain Co., 13 OSHC (BNA) 1084 (O.S.H.R.C. Feb. 4, 1987))

${ }^{8}$ When assessing civil penalties under 29 U.S.C. $\$ 666(\mathrm{j})$, the Review Commission shall consider "the size of the employer's business, gravity of the violation, good faith, and prior history of violations." J. A. Jones Construction Co., 15 BNA OSHC 2201 (No. 87-2059, 1993). Gravity of the harm depends on "the number of employees exposed, duration of exposure, precautions taken against injury, and the likelihood that an injury would result." Manson Construction Company, 26 BNA OSHC 1568 (citing J. A. Jones Construction Co., 15 BNA OSHC at 2213-14)
} 


\section{General Duty Clause}

\section{U.S.C. § 654: Duties of Employers and Employees}

(a) Each employer -

(1) shall furnish to each of his employees employment and a place of employment which are free from recognized hazards that are causing or are likely to cause death or serious physical harm to his employees

(2) shall comply with occupational safety and health standards promulgated under this chapter

(b) Each employee shall comply with occupational safety and health standards and all rules, regulations and orders issued pursuant to this chapter which are applicable to his own actions and conduct

The General Duty Clause imposes a duty on employers to furnish to their employees a workplace free of reasonably preventable conditions that may cause potential physical harm. ${ }^{9}$ An employer is an individual or non-governmental entity engaging in activities that affect intra-state or inter-state commerce. ${ }^{10}$ An employer is not incremental insurance for the employee's safety. ${ }^{11}$ Otherwise, the Occupational Safety and Health Administration (OSHA) would disincentivize compliance efforts or the hiring of human labor; an employer would hold a duty to cure all hazard without recognition for mitigation efforts in the eventual worker's compensation calculus. ${ }^{12}$ An employer is only liable for recognizable hazards that beset preventable injury or death. ${ }^{13}$ There is an equal duty on employees to use and abide by health and safety standards, such as using personal protective equipment. ${ }^{14}$ Although the plain meaning of the statute places a duty upon employees, courts have concluded that the congressional intent of the Occupational Health and Safety Act (OSH Act) regulatory scheme to sanction employers. ${ }^{15}$ Therefore, the employer retains sole responsibility for OSH Act compliance. ${ }^{16}$ The statute unambiguously states the employees' have a duty to learn and comply with the OSH Act and OSHA safety and health standards, but courts shift the responsibility to the employer, requiring the employer's experience to

\footnotetext{
926 U.S.C. $\S 654(\mathrm{a})(1)$

${ }^{10} 26$ U.S.C. $\$ 652(5)$

${ }^{11}$ See, Ocean Elec. Corp. v. Sec'y of Labor, 594 F.2d 396, 399 (4th Cir. 1979).

${ }^{12}$ Id. at 401; See, Champlin Petroleum Co. v. OSHRC, 593 F.2d 637, 640 (5th Cir. 1979).

${ }^{13} 26$ U.S.C. $\$ 654(\mathrm{a})(1)$

${ }^{14} 29$ U.S.C. $\$ 654($ b), 29 C.F.R. $\$ 1926.28$ (A)

${ }^{15}$ See, U.S. v. Doig, 950 F.2d 411, 413 (7th Cir. 1991).

${ }^{16} I d$.
}

determine the necessary training prerequisite to its employees. ${ }^{17}$ No training is required if the employee would not be foreseeably exposed to the hazard. ${ }^{18}$

Actual knowledge is not a prerequisite to liability. The Secretary of Labor (the "Secretary") may illustrate an employer's constructive knowledge by asserting that the employer would have known if it exercised reasonable diligence. ${ }^{19}$ Conversely, the exercise of reasonable diligence is not entirely an affirmative defense for the employer. ${ }^{20}$ An employer has constructive knowledge of a safety violation if the employer fails to act with reasonable diligence. ${ }^{21}$ Reasonable diligence comprises a duty to create hazard abatement methods, ${ }^{22}$ "the duty to inspect the work area and anticipate hazards, the duty to adequately supervise employees and the duty to implement a proper training program and work rules." ${ }^{, 23}$ For example, an employer's internal safety rules program reveals an employer's constructive knowledge of a potential safety hazard, regardless of its sporadic enforcement or inadequacy with OSHA regulations. ${ }^{24}$ An employer's knowledge derives from its ability to reasonably foresee the unsafe conduct occur in the workplace and a supervisor's knowledge of an employee's OSH Act violation. ${ }^{25}$ Generally, the violator's knowledge is not vicariously imputed to the employer, including when a supervisor knowingly violates the OSH Act. ${ }^{26}$

A prevention measure only needs to be feasible: i.e., economically capable of abating the hazard. ${ }^{27}$ Determining where the costs outweigh the expected hazard avoidance depends on the circumstances. OSHA has no statutory duty to determine whether the costs of their standard on most employers bear a reasonable relationship to the benefits. ${ }^{28}$

A hazard is a potentially dangerous condition or activity that is either actually known to a particular employer or generally known to the industry. ${ }^{29}$ The

\footnotetext{
${ }^{17}$ See, Brennan v. OSHRC, 501 F.2d 1196, 1199 (7th Cir. 1974); Accord, General Dynamics Corp. v. OSHRC, 599 F.2d 453, 458 (1st Cir. 1979).

${ }^{18}$ See, Brennan, 501 F.2d at 1200 (1974).

${ }^{19}$ See, Carlisle Equipment Co. v. U.S. Sec'y of Labor and Occupational Safety, 24 F.3d 790, 793, (6th Cir.1994).

${ }^{20}$ See, Overaa Const. v. California Occupational Safety and Health Appeals Bd.,54 Cal. Rptr. 3d 154, 163 (Cal. App. 3d Dist. 2007); See, Baroid Div. of NL Industries, Inc. v. OSHRC, 660 F.2d 439, 447 (10th Cir. 1981).

${ }^{21}$ See, $N \&$ N Contractors, Inc. v. OSHRC, 255 F.3d 122, 127 (4th Cir. 2001).

${ }^{22}$ See, Baroid Div. of NL Industries, Inc., 660 F.2d at 447

${ }^{23} N$ \& $N$ Contractors, Inc., $255 \mathrm{~F} .3 \mathrm{~d}$ at 127.

${ }^{24}$ See, ComTran Group, Inc. v. U.S. Dept. of Labor, 722 F.3d 1304, 1311 (11th Cir. 2013)

${ }^{25}$ See, Quinlan v. Sec'y, U.S. Dept. of Labor, 812 F.3d 832, 839 (11th Cir. 2016) ${ }^{26}$ See, Quinlan, 812 F.3d at 842; See, Mountain States Tel. and Tel. Co. v. OSHRC, 623 F.2d 155, 158 (10th Cir.1980); Contra, Thomas G. Gallagher, Inc. v. OSHRC, 877 F.3d 1, 4 (1st Cir. 2017).

${ }^{27}$ See, American Textile Mfrs. Inst., Inc. v. Donovan, 452 U.S. 490, 507 (1981)

${ }^{28} \mathrm{Id}$. at 514 .

${ }^{29}$ See, St. Joe Minerals Corp. v. OSHRC, 647 F.2d 840, 845 (8th Cir. 1981).
} 
Secretary may establish constructive knowledge of the hazard by showing that "a reasonably prudent person familiar with the circumstances of the industry would have [foreseen and prevented] hazard." ${ }^{30}$ A hazard that is likely to cause death or serious physical harm to his employees is considered a recognized hazard. ${ }^{31}$ Therefore, death or serious harm need not actually occur to face liability. ${ }^{32}$ Similarly, an employee's injury does not establish a strict liability claim in favor of the employee or automatically evidence an OSHA standard or OSH Act violation. ${ }^{33}$ Although not dispositive, the employer may reduce the severity of a valid violation claim by presenting a history of an accident-free record on its OSHA Form $300 .^{34}$

\section{Burdens of Proof and Persuasion}

The Secretary of Labor always bears the initial burden of demonstrating sufficient evidence of a serious OSH Act violation to allow the fact-trier to infer a violation occurred. ${ }^{35}$ For a violation of $\S$ 654(a)(1), the Secretary of Labor must prove, "that the employer failed to render its workplace 'free' of a hazard which was 'recognized' and 'causing or likely to cause death or serious physical harm.",36 Specifically, the Secretary must establish, "(1) an activity or condition in the employer's workplace presented a hazard to an employee[;] (2) either the employer or the industry recognized the condition or activity as a hazard[;] (3) the hazard was likely to or actually caused death or serious physical harm[;] and (4) a feasible means to eliminate or materially reduce the hazard existed." 37

For a safety and health standard violation under $\S$ 654(a)(2), the Secretary must prove, (1) that the standard used to justify the safety citation applies; (2) that the employer failed to comply with the standard; "(3) that employees had access to the hazardous condition; and

\footnotetext{
${ }^{30}$ Donovan v. General Motors Corp., 764 F.2d 32, 37 (1st Cir. 1985) (quoting Cape \& Vineyard Div. of the New Bedford Gas and Edison Light Co. v. OSHRC, 512 F.2d 1148, 1152 (1st Cir.1975))

${ }^{31}$ See, 29 U.S.C. $\S 654(a)(1)$. See, 5 U.S.C. $§ 556(d)$ (Administrative Procedures Act requires the Secretary to satisfy its burden with reliable, probative, and substantial evidence).

${ }^{32}$ See, Babcock \& Wilcox Co. v. OSHRC, 622 F.2d 1160, 1164 (3rd Cir. 1980).

${ }^{33}$ See, Nat'l Realty \& Constr. Co. v. OSHRC, 489 F.2d 1257, 1265 (D.C. Cir. 1973); See,Cape \& Vineyard Div. of New Bedford Gas v. OSHRC, 512 F.2d at 1150 .

${ }^{34}$ See, Allis-Chalmers Corp., 542 F.2d 27, 31 (7th Cir. 1976). See, 29 U.S.C. $\S \S$ 657(c)(2)-(c)(3); IV. Federal Agency Recordkeeping and Reporting Requirements., OSHA Field Op Man. Sec IV, Ch. 13 (D.O.L.).

${ }^{35}$ See, D.A. Collins Const. Co., Inc. v. Sec'y of Labor, 117 F.3d 691, 694 (2nd Cir. 1997); See, Prima Facie Case, Black's Law Dictionary (10th ed. 2014).

${ }^{36}$ Natl. Realty \& Const. Co., Inc. v. OSHRC, 489 F.2d 1257, 1265, (D.C. Cir. 1973).

${ }^{37}$ SeaWorld of Fla., LLC v. Perez, 748 F.3d 1202, 1207 (D.C. Cir. 2014) (quoting Fabi Constr. Co. v. Sec'y of Labor, 508 F.3d 1077, 1081 (D.C.Cir.2007)).
}

(4) that the employer had actual or constructive knowledge of the violation." 38

Although an employee can violate the General Duty Clause, under $\S 654(\mathrm{~b})$, no case law discusses the burden of proof for employee violations, for Congress never intended to sanction employees. ${ }^{39}$ However, if Congress amended the OSH Act or the courts recognized a claim against the employee violation, then the Secretary would still have the burden of proving the elements of the violation and the General Duty Clause. ${ }^{40}$

The employer is initially responsible to comply with OSHA standards while being limited to a feasibility standard. ${ }^{41}$ The infeasibility defense is discussed in a later section. The burden of proof can fall on OSHA, instead of the Secretary, to show substantial evidence that the safety standard is economically and technologically feasible. ${ }^{42}$ Once the OSHA standard is considered feasible, the employer may (1) rely on the Secretary and OSHA's safety standards $^{43}$ and (2) possess knowledge of alternative measures the industry uses to prevent hazards. ${ }^{44}$

Firstly, faithful reliance on OSHA administrative safety standards shall absolve an employer of the liability for an injury the hazard addresses only when the employer lacks knowledge that the OSHA standard is inadequate, or the workplace conditions make the OSHA standard inadequate to protect an employee from a recognized hazard. ${ }^{45}$

Second, the employer must demonstrate a remedy in the OSHA standard is infeasible under her workplace circumstances, ${ }^{46}$ which may incorporate the Impossibility or Greater Hazard Defense. ${ }^{47}$ The Secretary will argue that a reasonably prudent employer would have recognized and protected against the hazard while citing the employer's industry custom and practice. $^{48}$ The Secretary may introduce practicable prevention measures substantiated by evidence that

\footnotetext{
${ }^{38}$ See, P. Gioioso \& Sons, Inc. v. OSHRC, 675 F.3d 66, 72 (1st Cir. 2012).

${ }^{39}$ See, Atlantic \& Gulf Stevedores, Inc., 534 F.2d 541, 553 (3rd Cir. 1976)

${ }^{40}$ See, Natl. Realty \& Const. Co., Inc., 489 F.2d at 1263.See also, 5 U.S.C. § 556(d).

${ }^{41}$ See, generally, Brock v. Dun-Par Engineered Form Co., 843 F.2d 1135, 1139 (8th Cir. 1988)

${ }^{42}$ See, Color Pigments Mfrs. Ass'n v. Occupational Safety \& Health Admin., 16 F.3d 1157, 1161 (11th Cir. 1994) (quoting AFL-CIO v. Occupational Safety \& Health Admin., 965 F.2d 962, 980 (11th Cir. 1992)).N. Am.'s Bldg. Trades Unionsv. Occupational Safety \& Health Admin., 878 F.3d 271, 281 (D.C. Cir. 2017) ("The Secretary has delegated his authority to OSHA").

${ }^{43}$ See, Brock v. Dun-Par Engineered Form Co., 843 F.2d 1135, 1139 (8th Cir. 1988).

${ }^{44}$ See, Intl. Union, United Auto., Aerospace and Agr. Implement Workers of Am. v. Gen. Dynamics Land Sys. Div., 815 F.2d 1570, 1577 (D.C. Cir. 1987).

${ }^{45} \mathrm{Id}$.

${ }^{46}$ See, Ace Sheeting \& Repair Co. v. OSHRC, 555 F.2d 439, 441 (5th Cir. 1977).

${ }^{47}$ See, E \& R Erectors, Inc. v. Sec'y of Labor, 107 F.3d 157, 163 (3rd Cir. 1997).

${ }^{48}$ See, Tri-State Roofing \& Sheet Metal, Inc. v. OSHRC, 685 F.2d 878, 880 (4th Cir. 1982).
} 
would lead a reasonably minded person to accept the conclusion that the evidence corroborated. ${ }^{49}$

The burden of persuasion for the Secretary and Employer when making their cases is "by a preponderance of the evidence." $" 50$ This is a figurative measurement of the amount of evidence both parties must present to bolster their arguments. The administrative law judge or judge will then decide whether she is convinced that the facts asserted by a proponent are more probably true than false. ${ }^{51}$ The Substantial Evidence test applies to Judicial Review ${ }^{52}$ of OSHA's standards and their legislative policy decisions. ${ }^{53}$ The test also applies when an Employer appeals a decision and order from the Occupational Health Safety Review Commission ("Commission") to the appropriate US Circuit Court of Appeals where the violation occurred or where the employer has its headquarters: i.e., its principal place of business. ${ }^{54}$ The evidence on record is considered substantial when enough relevant evidence leads a reasonable mind to possibly accept the conclusion proposed. ${ }^{55}$ For OSHA policy determinations, the court evaluates whether the Secretary's actions are consistent with the statutory language and purpose of the OSH Act and the Secretary's actions are reasonable exercises of decision-making power within the limits imposed by Congress. ${ }^{56}$

\section{Statute of Limitations}

The Secretary or OSHA must issue a citation within six-month from the date the alleged violation occurred. ${ }^{57}$ A separate statute of limitations may apply if the

${ }^{49}$ See, 29 U.S.C. $\$ 660(a)$; See, Empire-Detroit Steel Div., Detroit Steel Corp. v. OSHRC, 579 F.2d 378, 383 (6th Cir. 1978); See, Boise Cascade Corp., Composite Can Div. v. Sec'y of Labor and OSHRC, 694 F.2d 584, 589 (9th Cir. 1982)

${ }^{50}$ See, Carlisle Equip. Co. v. U.S. Sec'y of Labor and Occupational Safety, 24 F.3d 790, 7924 (6th Cir. 1994).

${ }^{51}$ See, Contour Erection \& Siding Sys., Inc., 18 OSHC (BNA) ๆ 1423 (A.L.J. Aug. 1, 1997)

${ }^{52}$ See, 29 U.S.C. 655 (f)

${ }^{53}$ See, Natl. Grain and Feed Ass'n v. Occupational Safety and Health Admin., 866 F.2d 717, 722 (5th Cir. 1988)

${ }^{54}$ See, 29 U.S.C. § 660(a); See, Danco Const. Co. v. OSHRC, 586 F.2d 1243, 1246 (8th Cir. 1978); See also, World-Wide Volkswagen Corp v. Woodson, 444 U.S. 286, 296-97 (1980) (No jurisdiction when the foreseeability of a lawsuit given its minimum contacts, conduct, and connections are too insignificant for purposeful availment purposes.).

${ }^{55}$ See, Natl. Grain and Feed Ass'n, 866 F.2d at 728 (quoting Universal Camera Corp. v. N.L.R.B., 340 U.S. 474, 477 (1951)).

${ }^{56}$ See, Texas Indep. Ginners Ass'n v. Marshall, 630 F.2d 398, 404 (5th Cir. 1980) (quoting American Petroleum Inst. v. Occupational Safety and Health Admin., 581 F.2d 493, 497 (5th Cir. 1978)).

${ }^{57}$ See, 29 U.S.C. \$ 658(c).See, Brennan v. Chicago Bridge \& Iron Co., 514 F.2d 1082, 1084 (7th Cir. 1975) ("the cited company will always be able to assert the affirmative defense of lack of "reasonable promptness" and presumably could subpoena the Area Director and his records to determine when the decision in fact was made"). employer is charged with federal criminal penalties, but a criminal claim would shift the case outside the OSH Act and its congressionally designated civil penalty. ${ }^{58}$ For federal criminal offenses, the statute of limitation starts from the date of the violation until five years after the offense was committed. ${ }^{59}$ This may differ depending on the crime charged.

From the date of the inspection, the Secretary must present evidence demonstrating that the violation happened prior to the citation or that the employees were exposed to a hazard prior to the citation. ${ }^{60}$ If the Secretary tries to amend the citation, an employer may file a response to the Secretary's motion to amend its citation by claiming, when applicable, that the amendment causes undue delay, prejudice against the employer from having a fair trial and futility of amendment. ${ }^{61}$ Similarly, a long delay between inspection and issuance of citation can create prejudice against the employer, ${ }^{62}$ which the employer should raise in its first pleading, also known as an Answer.

\section{Appeal Procedure}

An employer can contest a citation, which embodies the OSH Act and OSHA standard violation, by notifying the Secretary within 15 business days after receipt of the citation. ${ }^{63}$ An employer may seek an informal conference with the OSHA Area Director to establish an informal settlement agreement. ${ }^{64}$ Alternatively, an employer can appeal the citation by filing a Notice of Intent to Contest, which leads to litigation of the citation before the Commission. $^{65}$ As an administrative tribunal, the Commission has no authority to consider constitutional questions of the OSH Act. ${ }^{66}$ Constitutional questions may be raised in the initial proceeding, but the Commission shall not entertain those questions. ${ }^{67}$ The constitutional issue must be argued on appeal to a court of competent jurisdiction, such as the US Court of Appeals for the Federal Circuit. ${ }^{68}$ Once the final order by the Commission is entered, the employer must cure the

\footnotetext{
${ }^{58}$ See, S.A. Healy Co. v. OSHRC, 138 F.3d 686, 688 (7th Cir. 1998) (For the death of an employee, the double jeopardy clause does not forbid OSH Act civil penalties that were imposed after criminal punishment).

${ }^{59}$ See, 18 U.S.C. $\$ 3282$ (a)

${ }^{60}$ See, Gen. Elec. Co. v. OSHRC, 540 F.2d 67, 70 (2d Cir. 1976)

${ }^{61}$ Fed. R. Civ. P. 8(c), 15(b) and (c); See, Foman v. Davis, 371 U.S. 178, 182 (1962).

${ }^{62}$ See, Bancker Const. Corp. v. Reich, 31 F.3d 32, 35 (2nd Cir. 1994).

${ }^{63}$ See, 29 U.S.C. $\$ 659$ (c).See, also, 29 C.F.R. $\$ 1903.17(\mathrm{a})$

${ }^{64}$ See, 29 C.F.R. $\$ 1903.20$.

${ }^{65} I d$; See, Occupational Safety and Health Admin., Employer Rights and Responsibilities Following a Federal OSHA Inspection, OSHA 3000-11R, 11(2016), https://www.osha.gov/Publications/osha3000.pdf.

${ }^{66}$ See, Buckeye Indus., Inc. v. Sec'y of Labor, OSHRC, 587 F.2d 231, 235 (5th Cir. 1979).

${ }^{67}$ Id.; See, Mohawk Excavating, Inc. v. OSHRC, 549 F.2d 859, 861-62 fn. 3 (2nd Cir. 1977); Divesco Roofing and Insulation Co., 4 OSAHRC 339 (OSHRC 1973); See also, 28 U.S.C. § 1295.
} 
violation within the permitted grace period allotted to avoid an additional assessment of penalties. ${ }^{69}$ If the employer fails to cure and receives an assessment from the Secretary by certified mail, the employer may also appeal this assessment of penalties within 15 days to the Commission. ${ }^{70}$ After the Commission issues its final order, the employer may appeal, within 60 days after the Commission's order becomes final, to US Court of Appeals for the circuit in which the violation allegedly occurred or where the employer has its principal office. ${ }^{71}$

\section{Employer Procedural Defenses against OSHA Inspections}

An inspection can occur with or without notice. The Secretary will issue an advance inspection notice to stop imminent dangers. ${ }^{72}$ Advance notices of unprogrammed inspections are illegal as to protect the employee informing the Secretary of the employer's failure to rectify a hazard. ${ }^{73}$ An employer may put the local OSHA office on notice of its intent to not consent to OSHA investigations. A commercial building is entitled to protection against unreasonable searches and seizures without a warrant under the Fourth Amendment of the US Constitution and OSHA officers must respect the objection and terminate its attempt to inspect immediately. ${ }^{74}$ An inspector cannot threaten a citation to an employer for its failure to cooperate with a warrantless inspection. ${ }^{75}$ Sometimes an employer will consent to an OSHA inspection, but an employer may contact an attorney for advice prior to consenting. The inspector may acquire valid consent from a senior employee or the individual with the highest job title at a reasonable time when the inspector visits the workplace. ${ }^{76}$

\section{Warrants}

An administrative warrant, or its equivalent, is constitutionally required for there to be a nonconsensual OSHA inspection. ${ }^{77}$ An administrative warrant can be lawfully issued upon a showing of administrative probable cause. Administrative probable cause requires (1) specific evidence of an existing violation; or (2) a general administrative plan for the enforcement of the OSH Act,

\footnotetext{
${ }^{69}$ See, 29 U.S.C. $\$ 659(\mathrm{~b})$.

${ }^{70}$ See, 29 U.S.C. $\$ 659$ (b)

${ }^{71}$ See, 29 U.S.C. $\$ 660$ (a). See also, Consol.-Andy, Inc. v. Donovan, 642 F.2d 778,

779 (5th Cir. 1981)

${ }^{72}$ See, 29 C.F.R. § 1903.6.

${ }^{73}$ See, 29 U.S.C. $\$ \$ 657(f)(1), 666(f)$ (giving advance notice shall result in a fine of up to $\$ 1,000$ and/or a six month jail term).

${ }^{74}$ See, Marshall v. Barlow's, Inc., 436 U.S. 307, 311 (1978); See,29 C.F.R. § 1903.4 .

${ }^{75}$ See, Victor Microwave, Inc., 17 OSHC. (BNA) - 2141 (ALJ June 17, 1996); See also, Sarasota Concrete Co., 9 OSHC (BNA) - 1608 (Apr. 27, 1981).

${ }^{76}$ See, Downrite Engr. Corp., 21 OSHC (BNA) 1536 (A.L.J. Feb. 6, 2006)

${ }^{77}$ See, Donovan v. Federal Clearing Die Casting Co., 655 F.2d 793, 796 (7th Cir. 1981)
}

derived from neutral inspection criteria. ${ }^{78}$ The magistrate issuing the warrant does not need to have a reasonable belief that a violation will be found; however, the magistrate must have a reasonable belief that the OSHA standard has been violated to issue a valid administrative warrant. ${ }^{79}$ An OSHA officer's desire to acquire a warrant to harass an employer is unreasonable, even if the officer contemporaneously believes a possible violation exists. ${ }^{80}$ Political motivations and retaliatory employee requests for inspections lack any administrative probable cause. ${ }^{81}$ The Secretary cannot use past OSH Act violations or an employer's compliance history to establish the specific evidence requirement of probable cause. ${ }^{82}$ Public policy discourages blacklisting employers because a single citation should not create a perpetual right of unceasing inspections for the Secretary. ${ }^{83}$

The employer may ask the basis for the warrant because the OSHA inspector should be able to articulate the scope and purpose of the search, which is constitutionally reasonable and authorized by Title 29 of the USC or other administrative standards. ${ }^{84}$ The OSHA inspector must also present credentials ${ }^{85}$ and prove the validity of an unexpired warrant. A warrant does not permit the inspector to unreasonably disrupt business operations. ${ }^{86}$ The employer must receive a copy of the request for inspection notice no later than at the time of the inspection. ${ }^{87}$ The notice must have particularity, demonstrating reasonable grounds for the inspection. ${ }^{88}$ For unprogrammed inspections, the identities of the individuals notifying the local OSHA office shall remain protected if those individuals request to preserve their anonymity. ${ }^{89}$ An inspector can only gain access to areas of the commercial property related to the scope of the warrant. ${ }^{90}$ OSHA's authority to inspect and enter the

\footnotetext{
${ }^{78}$ See, Marshallv. Barlow's, Inc., 436 U.S. at 323 (1978)

${ }^{79}$ See, Balsa U.S.A., Inc. v. Austin, 60 F. Supp. 2d 723, 730 (W.D. Mich. 1999); See, Marshall v. Horn Seed Co., 647 F.2d 96, 101 (10th Cir. 1981).

${ }^{80}$ See, Martin v. Int'l Matex Tank Terminals-Bayonne, 928 F.2d 614, 624 (3d Cir. 1991).

${ }_{81} 29$ U.S.C. $\$ 657$ (f) (the employee's written notice of a possible OSHA violation requires particularity. Secretary determines there are reasonable grounds to believe that such violation or danger exists.)

${ }^{82}$ See, Donovan, 655 F.2d at 798; See, Marshall v. Weyerhaeuser Co., 456 F.Supp. 474, 482 (D.N.J. 1978) ${ }^{83} \mathrm{Id}$.

${ }^{84}$ See, Marshall v. Barlow's, Inc., 436 U.S. at 323

${ }^{85} \mathrm{See}, 29$ U.S.C. $\$ 657(\mathrm{a})$

${ }^{86}$ See, 29 C.F.R. § 1903.7; See, Keco Industries, Inc., 7 OSHC (BNA) ๆ 2048 (O.S.H.R.C. Dec. 19, 1979)

${ }^{87}$ See, 29 USC $\$ 657(f)(1)$.

${ }^{88}$ See, Camara v. Mun. Ct. of City and County of San Francisco, 387 U.S. 523 , 535 (1967).

${ }^{89}$ See, 29 U.S.C. 657 (f)

${ }^{90}$ See, e.g., Donovan v. Fall River Foundry Co., 712 F.2d 1103, 1108 (7th Cir 1983) (Plantwide inspection of a facility whenever employees complain to OSHA about specific conditions is not mandated. "If a general warrant is sought, there should be some evidence presented to the magistrate supporting the belief by OSHA that the deleterious conditions may also be present in other portions of the facility.").
} 
premises without delay does not supersede the employer's constitutional right to unreasonable seizures and use of warrants without probable cause. ${ }^{91}$ An employer may request to have time to acquire an attorney to be present during the investigation..$^{92}$ Once a valid warrant is presented, the employer may not continue to refuse the inspection, besides requesting an attorney, as to avoid a fine for unreasonably delaying the inspection. ${ }^{93}$ During the wait for the attorney's arrival or on the day of the inspection, the employer could cure any defects before the inspection begins. An employer and the owner of the property should accompany the inspector at all times both to ensure the inspector's safety and to enforce the scope of the warrant. ${ }^{94}$ The failure to grant the employer its walkaround rights is an affirmative defense to vacate the citation, but the employer must also show the harm endured by the Secretary's or OSHA's procedural violations. $^{95}$ The employer can make alterations to the premises before the inspection. ${ }^{96}$ Silence or failure to object to the inspection constitutes implied irrevocable consent. $^{97}$ Although an uninformed employer lacking knowledge of their right to object to a warrantless search can be a defense, an OSHA inspector asking for consent or requesting entry creates a degree of voluntariness diminishing this argument. ${ }^{98}$ An internal policy may be implemented to have all higher-ranked employees understand that an OSHA officer inspection may be rejected without a warrant.

\section{Consent and Exceptions}

An employer can consent to an OSHA inspection. ${ }^{99}$ Consent may be withdrawn by an unequivocal act or statement. ${ }^{100}$ An employer's clear and repeated inconsistent conduct with its consent effectuates a withdrawal of its consent. ${ }^{101}$ The employer cannot raise a Fourth Amendment violation unless the inspection was not within the scope of consent. ${ }^{102}$ The Secretary will

\footnotetext{
${ }^{91}$ See, U.S. Const. Amend. IV.

${ }^{92}$ See, 29 U.S.C. $\$ 657($ e); 29 C.F.R. $\$ 1903.8$. (Walk-around rights)

${ }^{93}$ See, Matter of Trinity Industries, Inc., 876 F.2d 1485, 1494 (11th Cir. 1989). See, also, 29 USC $\$ 657(\mathrm{a})(1)$

${ }^{94}$ See, 29 U.S.C. $\$ 657(\mathrm{e})$.

${ }^{95}$ See, Frank Lill \& Son, Inc. v. Sec'y of Labor, 362 F.3d 840, 846 (D.C. Cir. 2004); See, Pullman Power Products, Inc. v. Marshall, 655 F.2d 41, 44 (4th Cir 1981)

${ }^{96}$ See, 29 U.S.C. $§ 659$ (b) (stating the period permitted for correction of cited OSHA violations does not to begin to run until entry of final order by Commission in case of any review proceedings)

${ }^{97}$ See, Simplex Time Recorder Co. v. Secretary of Labor, 766 F.2d 575, 581 (D.C. Cir. 1985)

${ }^{98}$ Id.; See also, 29 C.F.R. § 1903.4(a).

${ }^{99}$ See, Lakeland Enters. of Rhinelander, Inc. v. Chao, 402 F.3d 739, 745 (7th Cir. 2005)

${ }^{100}$ See, Fair v. Mills, 230 F.Supp.3d 1305, 1311 (M.D. Fla. 2017).

${ }^{101} I d$.

${ }^{102}$ See, Lakeland Enters. of Rhinelander, Inc., 402 F.3d at 745
}

still need to show, by a preponderance of the evidence, that the employer's consent to the search was freely and voluntarily given. ${ }^{103}$ Consent is void and the Fourth and Fourteenth Amendments are violated when the employer or its representative encounter an implied threat or covert force. ${ }^{104}$ The scope of consent under the Fourth Amendment is an objective reasonableness test: "What would a typical reasonable employer understood it consent[ed] to when the OSHA inspector was allowed entry?" 105 If specific details about the inspection are provided, the employer reasonably consented to the inspection of areas related to the specified complaint. ${ }^{106}$ Without specificity, nothing bars the inspector from reviewing the entire workplace without first informing the employer about the legal limits of the inspection. ${ }^{107}$ An inspector's discovery of an OSHA standard violation in an unconsented, warrantless area could implicate the fruit of the poisonous tree doctrine ${ }^{108}$ unless the violation was found in plain view. ${ }^{109} \mathrm{~A}$ readily observable violation $^{110}$ is substantially different from an inspector manipulating an object to view a violation when she lacks authority to inspect. ${ }^{111}$ Compare such findings with the open fields doctrine, where a worksite observable from a public place eliminates an employer's reasonable expectation of privacy for Fourth Amendment protection. ${ }^{112} \mathrm{~A}$ violation in plain view of the public does not require a warrant for further inspection because the OSHA inspector and the public have equal access to view the employer's violation and establish probable cause. ${ }^{13}$ An inspector may make observations from any location from which the public is not excluded: ${ }^{114}$ e.g., unoccupied or undeveloped lands. ${ }^{115}$ A trespass on

\footnotetext{
${ }^{103}$ See, Donovan v. A.A. Beiro Const. Co., Inc., 746 F.2d 894, 901 (D.C. Cir. 1984).

${ }^{104}$ See, Am. Airlines, Inc., 9 OSHC (BNA) - 1415 (A.L.J. Jan. 8, 1979) (referencing Schneckloth v. Bustamonte, 93 S.Ct. 2041, 2048, 412 U.S. 218, 228 (U.S.Cal. 1973))

${ }^{105}$ Cody-Zeigler, Inc., 19 OSHC (BNA) 1410 (O.S.H.R.C. May 09, 2001) (citing Florida v. Jimeno, 500 U.S. 248, 251, (1991)).

${ }^{106}$ See, Marshall v. N. Am. Car Co., 626 F.2d 320, 324 (3d Cir. 1980).

${ }^{107}$ See, Burkart Randall Div. of Textron v. Marshall, 625 F.2d 1313, 1326 (7th Cir. 1980); See, Marshall v. Barlow's, Inc., 436 U.S. 307, 333 (1978)

${ }^{108}$ See, Keco Industries, Inc., 7 OSHC (BNA) 92048 (A.L.J. Dec. 27, 1978)

${ }^{109}$ See, generally, United States v. Williams, 592 F.3d 511, 521 (4th Cir. 2010) (quoting, in part, Illinois v. Andreas, 463 U.S. 765, 771 (1983))

"once [governmental authority is] lawfully in a position to observe an item first-hand, its owner's privacy interest in that item is lost; the owner may retain the incidents of title and possession but not privacy. ... the mere observation of an item in plain view during the course of a lawful search does not implicate any Fourth Amendment concerns and therefore does not need to be justified by any exception to the warrant requirement."

${ }^{10}$ See, e.g., Nat'l Eng'g \& Contracting Co. v. Occupational Safety \& Health Admin., 928 F.2d 762, 766 (6th Cir. 1991).

${ }^{111}$ See, e.g., Jones Oregon Stevedoring Co., Respondent I.L.W.U., Local 21, Authorized Employee Representative, 12 O.S.H. Cas. (BNA) 1778 (A.L.J. Feb. 4,1986 ) ("the compliance officer's testimony that he had to take the hat in question in hand and examine it closely to confirm his initial suspicion that the hat did not meet the requirements of the standard persuades that the violation was not 'readily visible' or in 'plain view'").

${ }^{112}$ See, Tri-State Steel Constr. Inc., 15 OSHC (BNA) ๆ 1903 (O.S.H.R.C. Sept. 30, 1992).

${ }^{113}$ See, U.S. v. Oliver, 686 F.2d 356, 367 (6th Cir. 1982).

${ }^{114}$ Id. See, e.g., Ackermann Enterprises, Inc., OSHRC Docket No. 80-4971, p 2 (A.L.J. Aug. 7, 1981)

${ }^{15}$ See, Oliver v. U.S., 466 U.S. 170, 196 (1984)
} 
private property to make the observation from an area not excluded to the public cannot bar this exception. ${ }^{116}$

An inspector may always return later with a warrant ${ }^{117}$ or exercise the emergency doctrine. ${ }^{118}$ Courts find it reasonable, for public policy purposes, that a prompt inspection is upheld in emergency situations, even without a warrant. ${ }^{119}$ Although no guidance exists regarding OSHA emergencies, traditionally, emergencies for warrantless criminal law enforcement entries are concerned about the endangerment of life. ${ }^{120}$ The US Supreme Court has held that an OSHA inspector's urgency to inspect at a particular time or on a particular day insufficiently constitutes an emergency. ${ }^{121}$ The Secretary shall bear a higher burden for engaging in emergency inspections, for it must demonstrate the existence of an emergency - i.e., the exigency - and probable cause. ${ }^{122}$ Since most emergencies fall in the dominion of the police, it is unlikely that the local OSHA administrator shall receive prompt notice of an emergency contemporaneously occurring to enforce this exception. When an employer consents to a limited scope inspection and the endangerment is in plain view, the emergency doctrine may allow the inspector to go outside the consented scope of the inspection to mitigate the threat of a person's life.

Businesses enjoy a lower expectation of privacy compared to an individual's residence. ${ }^{123}$ This diminished expectation also applies to pervasively regulated, licensed industries as articulated in particular congressional legislation. ${ }^{124}$ Industries with such a history of government oversight, such as liquor ${ }^{125}$ and firearms, ${ }^{126}$ have no reasonable expectation of privacy. ${ }^{127}$ No Fourth Amendment exception applies to businesses that merely engage in interstate commerce, even though interstate commerce has historically been subject to government oversight. ${ }^{128}$ For regulated businesses, a warrantless inspection must be an integral part of the regulatory scheme designed to further the federal

\footnotetext{
${ }^{116}$ See, Ackermann Enterprises, Inc., 10 OSHC (BNA) ๆ 1709 (O.S.H.R.C. May $25,1982)$.

${ }^{117}$ See also, 29 C.F.R. § 1903.4(b)

${ }^{118}$ See, Camara v. Mun. Ct. of City and County of San Francisco, 387 U.S. 523, 539 (1967).

${ }^{119} I$.

${ }^{120}$ See, generally, U.S. v. Holloway, 290 F.3d 1331, 1337 (11th Cir. 2002).

${ }^{121}$ See, Camara, 387 U.S. at 540.

${ }^{122}$ See, generally, U.S. v. Holloway, 290 F.3d at 1337

${ }^{123}$ See, Dow Chem. Co. v. U.S., 476 U.S. 227, 237-38(1986) ("Government has 'greater latitude to conduct warrantless inspections of commercial property" because "the expectation of privacy that the owner of commercial property enjoys in such property differs significantly from the sanctity accorded an individual's home."”) (quoting Donovan v. Dewey, 452 U.S. 594, 598-599 (1981)).

${ }^{124}$ See, Brennan v. Buckeye Indus., Inc., 374 F.Supp. 1350, 1354 (S.D. Ga.1974).

${ }^{125}$ See, Colonnade Catering Corp. v. U.S., 397 U.S. 72,77 (1970).

${ }^{126}$ See,U.S. v. Biswell, 406 U.S. 311, 316 (1972)

${ }^{127}$ See, Marshall v. Barlow's, Inc., 436 U.S. 307, 313 (1978)

${ }^{128} I d$.
}

interest. $^{129}$ A warrantless search may be litigated. The courts shall test the legality of the search based on the statutory authority the Secretary had to inspect without a warrant and whether the search did not unjustifiably violate the regulated employer's entitled expectation of privacy. ${ }^{130}$ The court may also examine the constitutionality of the statute that should carefully limited in time, place and scope. ${ }^{131}$ The Secretary incurs a burdensome challenge when it must justify a warrantless search because, as the general rule indicates, warrantless, nonconsensual inspections of business premises are presumptively unreasonable. ${ }^{132}$

\section{Emplover Substantive Defenses to the General Dutv Clause}

An employer can find ways to discount the Secretary's showing that the General Duty Clause or any OSHA standards have been breached. When the court requests an employer to file an Answer to the Secretary's Petition, the employer must raise all affirmative defenses in its first Answer or Motion depending on the civil procedure of the court the employer is brought against. ${ }^{133}$ Affirmative defenses must be raised in the employer's first response, or else, the employer risks waiving those defenses. ${ }^{134}$ The employer may, nevertheless, seek leave by the court to raise the defense later in the proceeding, but courts permit a party to cure its failure to previously raise these defenses only if good cause is shown and if raising the defense does not prejudice the opposing party, the Secretary or OSHA, from having a fair, wellprepared trial. ${ }^{135}$ Discovery of new evidence to substantiate a defense could satisfy the good cause standard. ${ }^{136}$ The employer's undue delay in raising the defense at an earlier time cannot justify the denial of the employer's motion to amend unless the undue delay also prejudices the Secretary or the amendment is futile. ${ }^{137}$ Courts are given deference when exercising their discretion to allow or deny a motion. ${ }^{138}$ An employer

\footnotetext{
${ }^{129}$ See, Dunlop v. Hertzler Enterprises, Inc., 418 F. Supp. 627, 632 (D.N.M. 1976). ${ }^{130}$ See, Dunlop, 418 F. Supp. at 631-32 (citing U.S. v. Biswell, 406 U.S. 311, 315 (1972)).

${ }^{131}$ See, U.S. v. Biswell, 406 U.S. 311, 315 (1972).

${ }^{132}$ See, Camara v. Mun. Court of City \& Cty. of San Francisco, 387 U.S. 523 528-29 (1967). See, See v. City of Seattle, 387 U.S. 541, 543 (1967) ("The businessman, like the occupant of a residence, has a constitutional right to go about his business free from unreasonable official entries upon his private commercial property. The businessman, too, has that right placed in jeopardy if the decision to enter and inspect for violation of regulatory laws can be made and enforced by the inspector in the field without official authority evidenced by warrant.")

${ }^{33}$ See, Fed. R. Civ. P. 8(c)

${ }^{134}$ See, Charpentier v. Godsil, 937 F.2d 859, 863 (3rd Cir. 1991) (citing Fed. R. Civ. P. 8(c)).

${ }^{135}$ See, Fed. R. Civ. P. 15(a), (c); 16(b). See, Charpentier, 937 F.2d at 863-64

${ }^{136}$ See, Macias v. Cleaver, 1:13-CV-01819-BAM (E.D. Cal. Apr. 8, 2016)

${ }^{137}$ See, Bowles v. Reade, 198 F.3d 752, 758 (9th Cir. 1999); See also, Griggs v. Pace American Group, Inc., 170 F.3d 877, 880 (9th Cir. 1999).

${ }^{138}$ See, Gen. Elec. Co. v. Joiner, 522 U.S. 136, 143 (1997). See, generally, O'Dell v. Hercules, Inc., 904 F.2d 1194, 1200 (8th Cir. 1990) ("The trial court is in the
} 
may appeal to an appellate court for an abuse of discretion review ${ }^{139}$ of the Commission's or lower court's determination that denied the employer's motion or denied the admissibility of evidence. ${ }^{140}$

\section{Multi-Employer Doctrine}

Under the Multi-Employer Doctrine, an employer's scope of liability covers hazards it creates or controls that could expose its hired employees and all other employees working within the same workspace to the recognized harm, even if the workspace includes employees of another employer. ${ }^{141}$ In one case, the Fifth Circuit expressly rejected this doctrine and instead, relies on a respondent superior theory to ensure employees are properly operating a vehicle. ${ }^{142}$ Generally, the respondent superior theory does not account for the purpose of the OSH Act and is an insufficient legal basis to determine the OSH Act liability. ${ }^{143} \mathrm{~A}$ contractor is not responsible for acts of his subcontractors or their employees, especially when the employees are not complying with occupational health and safety standards. ${ }^{144}$ This defense defers responsibility to the actual creator of the harm, another employer's employee, who failed to abate the harm. ${ }^{145}$ The injured-employee's employer remains liable if it possesses actual knowledge of the hazard or the hazard was easily discoverable. ${ }^{146}$ An employer that is not responsible for creating or controlling the hazard must take reasonable measures to ensure the safety of its employees. ${ }^{147}$ Although not always practicable, persuading the responsible employer to fix its mistake or imposing a work-stoppage in the area where the hazard exists provides a safe-harbor for employers trying to avoid a safety violation under the

best position to determine whether the alleged error affected the substantial rights of any party sufficient to warrant a new trial. Therefore, the trial court's decision deserves considerable deference.").

${ }^{139}$ See, Evans v. Eaton Corp. Long Term Disability Plan, 514 F.3d 315, 322 (4th Cir. 2008) ("the abuse of discretion standard requires a reviewing court to show enough deference to a primary decision-maker's judgment that the court does not reverse merely because it would have come to a different result in the first instance."). See, Donovan v. Adams Steel Erection, Inc., 766 F.2d 804, 807 (3d Cir. 1985) (To determine whether [the Commission] has acted arbitrarily or abused its discretion, the reviewing court "must consider whether the decision was based on a consideration of the relevant factors and whether there has been a clear error of judgment.") (citing Citizens to Pres. Overton Park, Inc. v. Volpe, 401 U.S. 402, (1971), abrogated by Califano v. Sanders, 430 U.S. 99 (1977)). ${ }^{140}$ See, O'Dell v. Hercules, Inc., 904 F.2d 1194, 1200 (8th Cir. 1990).

${ }^{141}$ See, Universal Const. Co., Inc. v. OSHRC, 182 F.3d 726, 728 (10th Cir. 1999)

${ }^{142}$ S.E. Contractors, Inc., 8 OSAHRC 285 (O.S.H.R.C. 1974) (overruled by S.E. Contractors, Inc v. Dunlop, 512 F.2d 675 (5th Cir. 1975)).

${ }^{143}$ See, Richmond Block, Inc., 6 OSAHRC 180 (O.S.H.R.C. 1974).

${ }^{144}$ See also, Southeast Contractors, Inc. v. Dunlop, 512 F.2d 675 (5th Cir.1975).

The Fifth Circuit Court of Appeals has jurisdiction over Texas, Louisiana, and Mississippi federal district courts.

${ }^{145}$ See, Bragunier Masonry Contractors, Inc. v. Maryland Com'r of Labor and Indus., 684 A.2d 6, 10 (Md. Spec. App. 1996)(citing Grossman, 4 OSHC 1175, 1189 (BNA) (1976) OSAHRC LEXIS 528, 13)

${ }^{146} \mathrm{See}, \mathrm{Id}$. at 16.

${ }^{147}$ See, Electric Smith, Inc. v. Sec 'y of Labor, 666 F.2d 1267, 1270 (9th Cir. 1982).
Multi-Employer Doctrine. ${ }^{148}$ An OSH Act violation cannot provide a basis to create a cause of action, but the employer or employee could seek a cause of action under a common law tort claim or other statutory rights, duties, or liabilities of employers and employees under any employment law regarding workplace injury. ${ }^{149}$

The OSH Act imposes an indirect liability for violations of specific industry standards even though the employers are not in that specific industry or the employees harmed are not employees of the employer responsible for the violation. ${ }^{150}$ Under the OSHA Multi-Employer Citation Policy, OSHA Instructions CPL 02-00-124, the Secretary must: (1) determine which employer at the worksite created, exposed, corrected, or controlled the hazard; and (2) determine whether each employer fulfilled their roles under the OSHA standards. ${ }^{151}$ The employers on the worksite are held to a uniform reasonable care standard. ${ }^{152}$ An exception applies to the controlling employer - the employer assigned supervisory authority over the entire worksite through contract or trade practice - that has to exercise reasonable care to prevent and detect violations on site. ${ }^{153}$ The controlling employer is not presumed to have the expertise to know how to inspect or abate hazards, but once discovered, the controlling employer must prevent or correct a violation, or delegate another employer to prevent or correct the violation. ${ }^{154}$ To avoid the controlling employer liability, an employer could avoid assuming general supervisory authority under a contract, unless the job generally requires the employer to assume a supervisory role over the worksite.

An employer can easily question the OSHA MultiEmployer Citation Policy since it has never been formally promulgated as a rule under the notice and comment provisions of the Administrative Procedure Act. ${ }^{155}$ Federal Agency instructions or policy are not legally binding in court. ${ }^{156}$ Nevertheless, an agency's interpretation of implementing a statute or regulation is entitled to judicial deference only if the interpretation is not contrary to the statute's or regulation's plain meaning. ${ }^{157}$ Therefore, an employer may claim the

\footnotetext{
${ }^{148} I d$.

${ }^{149}$ See, 29 U.S.C. § 653(4); See, Figgs v. Bellevue Holding Co., 652 A.2d 1084, 1091 (Del. Super. 1994); See, Solis v. Summit Contractors, Inc., 558 F.3d 815, 829 (8th Cir. 2009)

${ }^{150}$ See, Anthony Crane Rental, Inc. v. Reich, 70 F.3d 1298, 1305, (D.C. Cir. 1995) ${ }^{151} \mathrm{See}$, U.S. Dept. of Labor, Multi-Employer Citation Policy OSHA Instructions $\begin{array}{llcr}\text { CPL } & \text { 02-00-124, } & \text { (Dec. } & 10,\end{array}$ https://www.osha.gov/pls/oshaweb/owadisp.show_document?p_table=DIRECTI VES\&p_id=2024

VES\&
${ }^{152} I d$.

${ }^{153} \mathrm{Id}$

${ }^{54} \mathrm{Id}$

${ }^{155}$ See, IBP, Inc. v. Herman, 144 F.3d 861, 866 (D.C. Cir. 1998)

${ }^{156}$ See, Webb v. Hodel, 878 F.2d 1252, 1255 (10th Cir. 1989).

${ }^{157}$ See, Advanta USA, Inc. v. Chao, 350 F.3d 726, 728 (8th Cir. 2003). See, Solis v. Summit Contractors, Inc., 558 F.3d 815, 823 (8th Cir. 2009) (If "the Secretary's interpretation differs from [the Commission's], [the appellate court] afford[s] substantial deference to the Secretary's reasonable interpretation.").
} 
instructions are creating new law and are outside the scope of the plain meaning of the OSH Act.

In summary, the case law from the Commission has simplified the Multi-Employer Doctrine. Therefore, for an employer to bar the Secretary, or employees under a private tort lawsuit, from attaching liability to both the wrongdoer and the employer, "the employer must prove:

(1) it did not create the violative condition to which its employees were exposed;

(2) it did not control the violative condition, so that it could not itself have performed the action necessary to abate the condition as required by the standard; and

(3) it took all reasonable alternative measures to protect its employees from the violative condition" 158

\section{Property Ownership of the Premises}

To make matters worse, the landowner hiring all these employers and employees may be required to warn them of hazards on the premises or furnish protection from dangers. ${ }^{159}$ United States property law is a domain left to the states, meaning each state may have a different approach. ${ }^{160}$ Generally, when a property owner grants someone permission to enter the property for a mutual business purpose, the worker is an invitee. ${ }^{161}$ The property owner owes a duty to warn and protect invitees of latent dangers, which she knows or should have known about. ${ }^{162}$ Conversely, if someone can enter the property for his own business, pleasure or convenience, the property owner has granted the person a license, where the property owner need only warn the licensee. ${ }^{163}$ Thus, a property owner must search for dangers on behalf of invitees and merely know about dangers, not necessarily should have known, for licensees. ${ }^{164}$ Some states have abolished this distinction, and instead, these states created a general duty of reasonable care in all the circumstances that the property owner or occupier owes to all lawful visitors. ${ }^{165}$ Under a general duty to invitees, property owners are held to a standard weighing the foreseeability of the harm against the interest that must be sacrificed to avoid the risk of injury. ${ }^{166}$ Although the property owner need not

\footnotetext{
${ }^{158}$ Wayne J. Griffin Electric, Inc., 26 BNA OSHC 1786 (No. 15-0858, 2017) (quoting Rockwell Int'l Corp., 17 BNA OSHC 1801, 1808 (No. 93-45, 1996)). ${ }^{159}$ See, e.g., Ellis v. Chase Commc'ns, Inc., 63 F.3d 473, 475-76 (6th Cir. 1995). ${ }^{160}$ See, Washlefske v. Winston, 234 F.3d 179, 183 (4th Cir. 2000); See, Boggs v. Boggs, 520 U.S. 833, 840 (1997)

${ }^{161}$ See, Linn v. U.S., 979 F.Supp. 521, 523 (E.D. Ky.1997).

${ }^{162}$ See, Cain v. Bovis Lend Lease, Inc., 817 F. Supp. 2d 1251, 1272 (D. Or. 2011).

${ }^{163}$ See, Linn, 979 F.Supp. at 523

${ }^{164} I d$.

${ }^{165}$ See, Mounsey v. Ellard, 297 N.E.2d 43, 52 (Mass. 1973).

${ }^{166}$ See, Smith v. Arbaugh's Restaurant, Inc., 469 F.2d 97, 100, 106 (D.C. Cir. 1972)
}

endure unreasonable burdens to keep the property safe, the property owner must make the premises for all visitors reasonably safe. ${ }^{167}$

A breach of a duty with substantial damages may result in a negligence claim. ${ }^{168}$ There are two duties aimed to protect the employee. The employer holds a duty to protect its employees from recognized hazards using health and safety standards, per the General Duty Clause. ${ }^{169}$ The owner of the worksite premises, which may also be the employer, holds a duty to warn and protect all lawful visitors. ${ }^{170}$ The employee may argue negligence per se if the state law has a statute enacted to protect a class of persons. Most states use the following elements to establish negligence per se:

"(1) there is [a] statute which prescribes certain actions or defines [a] standard of conduct, either explicitly or implicitly; (2) defendant violated [the] statute; (3) plaintiff is [a] member of [the] class sought to be protected by statute; and (4) harm or injury to plaintiff is generally of the type that [the] legislature, through statute, sought to prevent." 171

Property owners could prevail in a negligence case asserted by someone injured on the property raising negligence per $\mathrm{se}^{172}$ by disproving any of the four elements or hoping that the employee cannot sufficiently prove all the elements, ${ }^{173}$ which could be more or less depending on the state statute where the property is located. ${ }^{174}$ If the employee argues negligence per se due to an OSHA standard or an OSH Act violation, the employer may file a motion for summary disposition stating that 29 USC $\S 653(\mathrm{~b})(4)$ prohibits private causes of action of a violation of an OSHA regulation to establish negligence per se. ${ }^{175}$ For a court to take any action besides dismissing the case would upset the Congressional scheme for enforcing workplace safety through administrative penalties. ${ }^{176}$

\footnotetext{
${ }^{167} I d$.

${ }^{168}$ See, 29 U.S.C. $\$ 653(4)$

${ }^{169}$ See, 29 U.S.C. $\$ 654(a)$

${ }^{170}$ See, Cain v. Bovis Lend Lease, Inc., 817 F. Supp. 2d 1251, 1272 (D. Or. 2011). ${ }^{171}$ F.D.I.C. v. Schuchmann, 235 F.3d 1217, 1223 (10th Cir. 2000) (citing Archibeque v. Homrich, P.2d 820, 825 (N.M. 1975)) (emphasis added).

${ }^{172}$ See, Talley v. Danek Med., Inc., 179 F.3d 154, 158 (4th Cir. 1999) (negligence per se acknowledges a legislature's statutory or administrative standard of care; negligence per se is not a separate cause of action).

${ }^{173}$ See, also, Melerine v. Avondale Shipyards, Inc., 659 F.2d 706, 709 (5th Cir 1981).

${ }^{174}$ See, 28 U.S.C. $\S 1391$ (b)(2) (where a substantial part of the events occurred can determine venue). See, 59 A.L.R. Fed. 320, § 19, Torts, generally. ${ }^{175}$ See, e.g., Melerine v. Avondale Shipyards, Inc., 659 F.2d 706, 709 (5th Cir 1981) (Plaintiff used a worker's compensation act for maritime employees, instead of the $\mathrm{OSH}$ Act to bring a negligence action with a violation caused by negligence per se); See, Ries v. Nat'l R.R. Passenger Corp., 960 F.2d 1156, 1164 (3rd Cir. 1992); See, Crane v. Conoco, Inc., 41 F.3d 547, 553 (9th Cir. 1994) ("OSHA violations do not themselves constitute a private cause of action for breach."); See also, People of California v. Kinder Morgan Energy Partners, L.P., 569 F. Supp. 2d 1073, 1087 (S.D. Cal. 2008)

${ }^{76}$ See, Ries, 960 F.2d at 1164; See, Crane, 41 F.3d at 553.
} 
This is justifiable because not every accident creates a presumption of negligence and not every violation of a statute permits the argument of negligence per se. ${ }^{177}$ Although not applicable for OSH Act violations, the employer may need to disprove negligence per se in a worker's compensation or other state tort action.

A property owner may raise the defenses of contributory negligence and assumption of the risk in tort actions. ${ }^{178}$ Comparably, the assumption of the risk and contributory negligence defenses cannot exculpate an employer who is charged with violating an OSHA standard or the General Duty Clause. ${ }^{179}$ The modern legal trend to abolish the common law distinction between licensees and invitees imposes an equivalent general duty of safety. ${ }^{180}$ Since assumption of the risk and contributory negligence are invalid defenses for employers under the General Duty Clause, ${ }^{181}$ such claims may also be ineffective for property owners in these jurisdictions.

Although the OSH Act is federal law, federal preemption may not be a legitimate defense. A state making a statute protecting worker safety remains valid when the state does not conflict with preexisting OSHA regulations. ${ }^{182}$ To counter, the employer would need to demonstrate actual conflict: how complying with both state law and federal law was impossible. ${ }^{183}$ The State of New York finds Congress never intended the OSH Act to supplant local safety codes since the OSH Act lacks an express preemption clause. ${ }^{184}$ Inconsistently, the Congressional policy statement in $\S 651$ allows state governments to argue that the statute "improves the administration of [pre-existing] State occupational safety and health laws[;]" however, a counter-argument can arise discussing field preemption: "Congress declares it to be its purpose and policy, through the exercise of its powers to regulate commerce among the several States... to assure... [National] safe and healthful working conditions." 185 The US Supreme Court concludes that Congress intended to subject employers and employees to only one set of regulations: Either the OSH Act or State law. ${ }^{186}$ When

\footnotetext{
${ }^{177}$ See, Bedal v. Hallack \& Howard Lumber Co., 226 F.2d 526, 538 (9th Cir. 1955); See, Vanderwerf v. SmithKlineBeecham Corp., 414 F.Supp.2d 1023, 1026 (D. Kan. 2006)

${ }^{17}$ See, O'Neil v. Windshire Copeland Assoc., L.P., 197 F.Supp.2d 507, 512 (E.D. Va. 2002).

${ }^{179}$ See, REA Exp., Inc. v. Brennan, 495 F.2d 822, 825 (1974).

${ }^{180}$ See, Nelson v. Freeland, 349 N.C. 615, 622, 507 S.E. 2d 882, 886-87 (1998) ("nearly half of all jurisdictions in this country have judicially abandoned or modified the common-law trichotomy [of licensee, invitee, and trespasser]"). ${ }^{181}$ See, L. P. Kent Corp., 7 OSHC (BNA) 1030 (A.L.J. Nov. 13, 1978) (citing Nat'l Realty \& Const. Co. v. OSHRC, 489 F.2d 1257, 1266 n. 36 (D.C. Cir.

$1973)$ ).
${ }^{182}$ See, Steel Inst. of New York v. City of New York, 832 F.Supp.2d 310, 325 (S.D.N.Y.,2011).

${ }^{183} \mathrm{Id}$. at 330 .

${ }^{184} I d$. at 326

${ }^{185} 29$ U.S.C. $\$ \S 651(b),(b)(11)$

${ }^{186}$ See, Gade v. National Solid Wastes Management Ass'n, 505 U.S. 88, 99 (1992)
} (citing 29 U.S.C. $\$ 667(\mathrm{a})-(\mathrm{c})$ ). incorporating local law, the Secretary of State must approve a state plan for the law, the state law must not conflict with the OSH Act compliance and the preexisting state codes must not merely regulate the general public. ${ }^{187}$ Thus, an adverse party might strike the state occupational safety law equivalency if (a) the Secretary has not preapproved the law under 29 USC $\S 18$, or (b) OSHA regulations are enforced, but compliance with state law would conflict with the OSH Act. ${ }^{188}$

\section{Impossibility (Infeasibility) Defense}

An employer may plead impossibility of compliance or continued business operations as a defense. "The employer must prove[:]

(1) that compliance with a particular standard either is impossible or will render performance of the work impossible[;] and

(2) that the employer undertook alternative steps to protect its workers or that no such steps were available." 189

The employer would need to show that compliance with the OSHA standard would be more hazardous than noncompliance ${ }^{190}$ or that compliance would cause its business to become inoperative. ${ }^{191}$ Impossibility defenses are narrowly construed against the employer; thus, the employer needs cogent evidence to rebut the Secretary's establishment of an OSHA standard and OSH Act violation. ${ }^{192}$ The Secretary may further argue that the employer should have sought either a permanent or temporary variance under 29 USC $\S 655^{193}$ or alternative practical means were available. ${ }^{194}$ The employer is designated a greater evidentiary burden because, when promulgating an OSHA standard, the Secretary and OSHA had to demonstrate the economic and technological feasibility of the standard in a preenforcement review. ${ }^{195}$ The OSH Act requires a showing of the OSHA standard's economic feasible. ${ }^{196}$ OSHA must show that the compliance costs for employers to implement the OSHA standard will not threaten the existence or competitive structure of an industry, although some smaller firms may need to leave the

\footnotetext{
${ }^{187} I d$. at $107-108$

${ }^{188} \mathrm{Id}$. at $108-109$

${ }^{189}$ Harry C. Crooker \& Sons, Inc. v. OSHRC, 537 F.3d 79,82 (1st Cir. 2008) (emphasis added); E \& R Erectors, Inc. v. Sec'y of Labor, 107 F.3d 157, 163 (3rd Cir. 1997)

${ }^{190}$ See, Greyhound Lines-West v. Marshall, 575 F.2d 759, 762 (9th Cir. 1978)

${ }^{191}$ See, U. S. Steel Corp. v. OSHRC, 537 F.2d 780, 782 (3rd Cir. 1976).

${ }^{192}$ See, Greyhound Lines-W. v. Marshall, 575 F.2d 759, 762 (9th Cir. 1978)

${ }^{193}$ See, Taylor Bldg. Associates, 5 OSHC (BNA) 1083 (O.S.H.R.C. Mar. 3, 1977).

${ }^{194}$ See, E \& R Erectors, Inc, v. Sec' y of Labor, 107 F.3d 157, 164 (3rd Cir. 1997)

${ }^{195}$ See, 29 U.S.C. $\$ 655(\mathrm{~b})(5) ;$ See, Nat'l Mar. Safety Ass'n v.Occupational Safety \& Health Admin., 649 F.3d 743, 752, (D.C. Cir. 2011)

${ }^{196}$ See, N. Am.'s Bldg. Trades Unions v. Occupational Safety \& Health Admin., 878 F.3d 271, 296 (D.C. Cir. 2017) (citing 29 U.S.C. § 655(b)(5))
} 
industry entirely. ${ }^{197}$ An employer may always introduce evidence disproving OSHA's or the Secretary's ${ }^{198}$ presumption that a reasonable possibility exists for a typical firm in the industry to develop and install the safety equipment in its necessary work operations. ${ }^{199}$ The plain meaning of the word feasible means, "capable of being done." 200 Thus, feasibility can be discredited upon a showing of a severe adverse economic effect to the industry. ${ }^{201}$ The shifting of compliance costs to customers through increased prices may remedy the adjusted increase in costs of goods sold while threatening the ability to compete in the marketplace. ${ }^{202}$ Lower compliance costs can be achieved with differing occupational health and safety standards overseas and larger firms may assume the lost contribution margin better than smaller or new firms.

Numerous companies should not need to cease operations when reasonable alternative safety measures are available. ${ }^{203}$ Evidence of the company's operations becoming unprofitable due to new safety regulation and OSHA's failure to present substantial evidence of economic feasibility may allow an employer to justify an economic feasibility argument. ${ }^{204}$ OSHA need not conduct a cost-benefit analysis to determine feasibility, but OSHA must provide substantial evidence of the economic feasibility on all affected industries before promulgating a new standard. ${ }^{205}$

An employer may seek to lower the penalty before the Commission, which is the final authority to determine the penalty assessment. ${ }^{206}$ The employer can receive a good-faith credit to reduce or waive its $\mathrm{OSH}$ Act or OSHA standard violation penalty based on its size, ${ }^{207}$ newness and economic frailty, good faith compliance, and history of no repeat and willful OSH Act violations. ${ }^{208}$ An employer should reconsider asserting its intent to cease operations in the near future

\footnotetext{
${ }^{197} I d$.

${ }^{198}$ See, Id. at 281 ("The Secretary has delegated his authority to OSHA")

${ }^{199} \mathrm{See}, \mathrm{Id}$. at 296

${ }^{200}$ American Textile Mfrs. Inst., Inc. v. Donovan, 452 U.S. 490, 508-09 (1981)

${ }^{201}$ See, M.C. Dean, Inc. v. Sec'y of Labor, 505 Fed.Appx. 929, 937(11th Cir. 2013)(unpublished)

${ }^{202}$ See, Harry C. Crooker \& Sons, Inc. v. OSHRC, 537 F.3d 79, 84 (1st Cir. 2008).

${ }^{203}$ See, ASARCO, Inc. v. Occupational Safety and Health Admin., 746 F.2d 483, 501 (9th Cir. 1984) (“'long-term profitability and competitiveness' of the industry will not be threatened by the standard.").

${ }^{204}$ See, Harry C. Crooker \& Sons, Inc., 537 F.3d at 84

${ }^{205}$ Contra, 29 U.S.C. $\$ 655$; See, American Textile Mfrs. Inst., Inc., 452 U.S. 490 , 527-28, 536 (1981); See also, AFL-CIO v. Occupational Safety and Health Admin., 965 F.2d 962, 987 (11th Cir.1992).

${ }^{206}$ See, Brennan v. OSHRC, 487 F.2d 438, 442 (8th Cir. 1973).

${ }^{207}$ Only employers with 250 employees or less can qualify for a penalty reduction for size. See, Unifirst Corp., 2015 O.S.H. Dec. (CCH) $₫ 33423$ (A.L.J. Oct. 17, 2014); See, Jake's Fireworks, Inc., 26 O.S.H. Cas. (BNA) 1738 (A.L.J Apr. 24, 2017)

${ }^{208}$ See, 29 U.S.C. $\S 666(\mathrm{j})$; See, Dierzen-Kewanee Heavy Indus., Ltd., 22 OSHC (BNA) $\llbracket 1656$ (A.L.J. Feb. 17, 2009).
}

if dissolving the business is unrelated to the impossibility to operate and comply with the OSHA standard; otherwise, the court may dismiss the infeasibility argument due to its mootness: the standard has no effect on the business's future operations. ${ }^{209}$ Meanwhile, the civil penalty remains a ripe issue because ceasing all business operations causes no impact on the penalty balance due. ${ }^{210}$

According to the acclaimed book, Reading Law, the Unintelligibility Canon could render an OSHA standard inoperative. ${ }^{211}$ The Unintelligibility Cannon finds an intelligible text inoperative. ${ }^{212}$ The book discussed Justice Rehnquist's concurring analysis in AFL-CIO $v$. American Petroleum Institute ${ }^{213}$ to explain how Congressional legislative history can make an OSHA standard's feasibility requirement inoperative:

"A text means what the legislature intended it to mean and if it was clear in this case that there was no [uniform] meaning intended by a majority of Congress, then the product would be . . . a meaningless and hence inoperative provision., 214

OSHA cannot create a standard at its discretion to create an absolutely risk-free workplace irrespective of the costs. $^{215}$ Although OSHA may determine the thresholds for when a significant risk exists, without a scientific empirical rationale, ${ }^{216}$ the costs of implementation should not risk the destruction of the industry. ${ }^{217}$ When a government rule is ambiguous, the ambiguous rule should be construed against the drafter. ${ }^{218}$ "A statute is 'ambiguous' if it gives rise to more than one reasonable interpretation." "219 Many judges reserve a presumption in favor of the statute's validity ${ }^{220}$ until they are presented facts establishing that the government exceeded its powers. ${ }^{221}$ "[A] textually permissible interpretation that furthers rather than obstructs the document's purpose should be favored."222

To prevail with the Impossibility Defense, the employer shall need to investigate alternative hazard prevention measures that it can implement to the extent

\footnotetext{
${ }^{209}$ See, ASARCO, Inc. v. Occupational Safety and Health Admin., 746 F.2d 483, 500 (9th Cir. 1984)

${ }^{210}$ See, Reich v. OSHRC, 102 F.3d 1200, 1203 (11th Cir. 1997).

${ }^{211}$ See, Antonin Scalia \& Bryan A. Garner, Reading Law 134, 137 (2012)

${ }^{212} I d$. at 135

${ }^{213} 448$ US 607 (1980).

${ }^{214}$ Antonin Scalia \& Bryan A. Garner, Reading Law 134, 137 (2012).

${ }^{215}$ See, Indus. Union Dept., AFL-CIO v. Am. Petroleum Inst., 448 U.S. 607, 64042 (1980).

${ }^{216}$ Id. at 655

${ }^{217} I$ d. at $640-42$

${ }^{218}$ See, Hills Materials Co. v. Rice, 982 F.2d 514, 516 (Fed. Cir. 1992)

${ }^{219}$ See, Woods v. Carey, 722 F.3d 1177, 1181 (9th Cir. 2013).

${ }^{220}$ See, James Everard's Breweries v. Day, 265 U.S. 545, 560 (1924) (quoting Adkins v. Children's Hosp., 261 U.S. 525, 544 (1923)).

${ }^{221}$ See, Weaver v. Palmer Bros. Co., 270 U.S. 402, 410 (1926).

${ }^{222}$ See, Medina v. Catholic Health Initiatives, 877 F.3d 1213, 1226 (10th Cir. 2017) (quoting Antonin Scalia \& Bryan A. Garner, Reading Law 63-65 (2012)).
} 
feasible. $^{223}$ Thus, the employer uses its experience in performing its safety duties to find alternative means of practical protection for its employees. ${ }^{224}$ An employer can seek a variance proceeding to have the Secretary preapprove the alternative safety measure before being issued a citation, either due to the alternative measure's failure to facilitate safety or OSHA's discovery of the violation at a later date. ${ }^{25}$ Under no circumstances can an employer argue that its expertise and competency regarding necessary safety standards surpasse the Secretary's knowledge or the need to seek a variance. ${ }^{226}$ For two circuit court cases, the courts held impossibility of compliance with OSHA is unsubstantiated when an employer merely argues that compliance would be expensive or difficult and inconvenient. $^{227}$ Regardless of the standard's feasibility, a court shall evaluate whether the employer has done everything in its control to protect its employees by some means of protection. ${ }^{228}$ Courts recognize that literal compliance with a standard will not always be possible, and thus, the impossibility defense permits an employer to avoid liability for the direct noncompliance. $^{229}$

\section{Unpreventable Employee Misconduct}

Employers bear no duty to abate dangers caused by unforeseeable employee misconduct. ${ }^{230}$ An employee's idiosyncratic misconduct or suicidal exposure to a recognized hazard is beyond the employer's ability to exercise of reasonable diligence. ${ }^{231}$ Nevertheless, an employer bears the burden "to prove[:]

\footnotetext{
${ }^{223}$ See, Brock v. Dun-Par Engineered Form Co., 843 F.2d 1135, 1139 (8th Cir. 1988); Salco Constr., Inc., 21 OSHC (BNA) 1 1662, fn. 3 (A.L.J. Apr. 24, 2006) (citing Beaver Plant Operations, 18 OSHC (BNA) ๆ 1972 (O.S.H.R.C. Sept. 30, 1999)).

To prove the affirmative defense of infeasibility, an employer must show that: "(1) the means of compliance prescribed by the applicable standard would have been infeasible under the circumstances in that either (a) its implementation would have been technologically or economically infeasible or (b) necessary work operations would have been technologically or economically infeasible after its implementation; and (2) either (a) an alternative method of protection was used or (b) there was no feasible alternative means of protection." Salco Constr., Inc., 21 OSHC (BNA) ๆ 1662, fn. 3 (A.L.J. Apr. 24, 2006).

${ }^{224}$ See, Brock v. Dun-Par Engineered Form Co., 843 F.2d 1135, 1139 (8th Cir. 1988).

${ }^{225}$ See, 29 U.S.C. $\$ 655(d) ;$ See, 29 C.F.R. $\$ \$ 1905.10-1905.11$.

${ }^{226}$ See, Loomis Cabinet Co. v. OSHRC, 20 F.3d 938, 943 (9th Cir. 1994).

${ }^{227}$ See, Long Beach Container Terminal, Inc. v. OSHRC, 811 F.2d 477, 479 (9th Cir. 1987)

${ }^{228}$ See, J.F. White Contr. Co., 22 OSHC (BNA) 1917 (A.L.J. Sept. 08, 2009)

${ }^{229}$ Id. (citing Rockwell Intl. Corp., 17 OSHC (BNA) ๆ 1801 (O.S.H.R.C. Sept. 30, 1996)) (emphasis added).

${ }^{230}$ See, Pennsylvania Power \& Light Co. v. OHSRC, 737 F.2d 350, 354 (3rd Cir. 1984)

${ }^{231} I d$; See, 29 U.S.C. $\$ 666(\mathrm{k})$.
}

(1) it established work rules or policies designed to prevent the violation;

(2) it has adequately communicated these rules to its employees;

(3) it has taken steps to discover violations of the work rules; and

(4) it has effectively enforced these work rules when violations have been discovered." 232

After the Secretary has proven every element of a 29 USC $\S 654$ violation, the Secretary must also show the preventability of the employee's misconduct. ${ }^{233}$ The Secretary satisfies this burden by arguing how foreseeable the violation was given the employer's subpar safety precautions, employee training, and supervision. $^{234}$ However, the actual occurrence of hazardous conduct by employees is not, by itself, sufficient evidence of a General Duty Clause violation, even when the hazardous ${ }^{235}$ conduct caused the injury. ${ }^{236}$ The Secretary must present demonstrably feasible safety measures that would have materially reduced the probability of the conduct from occurring. ${ }^{237}$

A work rule is an employer directive that requires employees to act mindfully of workplace safety. ${ }^{238}$ The directive and its scope must be clearly communicated to employees, informing employees of their unambiguous mandatory obligation to act consistently with this directive. ${ }^{239}$ The work rule should outline the scope of the rule and the hazards it was designed to thwart. ${ }^{240}$ The work rule must detail the means used to eliminate and deter employees' exposure to the recognized hazard under an OSHA standard. ${ }^{241}$ The enactment of a work rule automatically concedes the

\footnotetext{
${ }^{232}$ Danis Shook Joint Venture XXV, 19 O.S.H. Cas. (BNA) ฯ 1497 (O.S.H.R.C. Aug. 2, 2001) (quoting Gem Indus., Inc., 17 O.S.H. Cas. (BNA) If 1861 (O.S.H.R.C. Dec. 6, 1996)) (emphasis added). See, OSHA Field Op Man. Sec VI(B)(1)(b), Ch. 5 (D.O.L.)

${ }^{233}$ See, Capital Elec. Line Builders of Kansas, Inc. v. Marshall, 678 F.2d 128, 130 (10th Cir. 1982)

${ }^{234} \mathrm{Id}$.

${ }^{235}$ Recall, a hazard is a potentially dangerous condition or activity that is either actually known to a particular employer or generally known to the industry. See, Donovan v. General Motors Corp., 764 F.2d 32, 37 (1st Cir. 1985).

${ }^{236}$ See, Nat'l Realty \& Const. Co., Inc. v. OSHRC, 489 F.2d 1257, 1267 (D.C. Cir. 1973).

${ }^{237}$ Id.

${ }^{238}$ See, Crowther Roofing \& Sheet Metal of Florida, 23 OSHC (BNA) ๆ 1361 (A.L.J. Oct. 15, 2010) (quoting J. K. Butler Builders, Inc., 5 OSHC (BNA) q 1075 (O.S.H.R.C. Feb. 25, 1977)).

${ }^{239} \mathrm{Id}$.

${ }^{240}$ See, Crowther Roofing \& Sheet Metal of Florida, 23 OSHC (BNA) ๆ 1361 (A.L.J. Oct. 15, 2010).

${ }^{241} I d$.; See, 29 U.S.C. $§ 652(8)$ ("The term 'occupational safety and health standard' means a standard which requires conditions, or the adoption or use of one or more practices, means, methods, operations, or processes, reasonably necessary or appropriate to provide safe or healthful employment and places of employment.").
} 
employer's awareness of a hazard, for the Secretary to establish a prima facie case of actual knowledge against the employer. ${ }^{242}$ Employer work rules can be drafted in a writing or a book and made readily available to employees on the worksite. ${ }^{243}$ In addition to repeated reminders and training, placing the written work rule in a convenient location diminishes the credibility of employees testifying that: (A) they lacked knowledge of the established policy to avoid the hazard; ${ }^{244}$ (B) the employer failed to communicate the work rule effectively; ${ }^{245}$ or (C) the employer's directive was discretionary or lacked specificity. ${ }^{246}$ The courts prefer work rules that are tailored to the particular working conditions and safety needs. ${ }^{247}$ Although verbatim copies of OSHA regulations may reduce litigation costs about the interpretation and effectiveness of the work rule, the rule's failure to facilitate and communicate workplace safety is the ultimate question posed to the judge. ${ }^{248}$

\section{Effective Communication}

The skill and experience of the employee is irrelevant evidence to excuse the employer from complying with OSHA standards and enforcing work rules. ${ }^{249}$ An employee's ability "to should have known better" is an illegitimate defense. A mere written acknowledgment cannot attest that the employee has read and comprehended the safety standards; the Secretary places a duty on the employer to enforce the recall (e.g., placing signs near the hazard) and comprehension of the safety rules on employees. ${ }^{250}$ Moreover, active instructions and actual demonstrations conducted regularly are given preference over passive training. ${ }^{251}$ A record of all on-the-job training, safety lectures and safety meetings, with summaries of the work rules taught, can evidence specific communication of a work rule for later litigation. ${ }^{252}$

\footnotetext{
${ }^{242} \mathrm{See}$, OSHA Field Op. Man. Sec III, Ch. 4(B)(6) (D.O.L.).

${ }^{243}$ See, generally, Consol. Edison Co. of New York, 8 O.S.H. Cas. (BNA) 1550 (A.L.J. Apr. 17, 1980)

${ }^{244}$ But see, e.g., Upshur Rural Elec. Coop. Corp., 7 O.S.H. Cas. (BNA) 1573 (A.L.J. May 23, 1979) ("Complainant does not contend that either respondent's foreman or any of the other employees who failed to observe respondent's safety policy, were unaware of respondent's safety policies").

${ }^{245}$ See, Wye Elec., Inc., 18 O.S.H. Cas. (BNA) ๆ 1445 (A.L.J. May 26, 1998)

${ }^{246}$ See, Pride Oil Well Serv., 15 O.S.H. Cas. (BNA) 1809 (O.S.H.R.C. Aug. 17, 1992).

${ }^{247}$ See, Pennsylvania Power \& Light Co. v. OSHRC, 737 F.2d 350, 359 (3rd Cir. 1984)

${ }^{248} I d$.

${ }^{249}$ See, CMC Elec., Inc. v. Occupational Safety and Health Admin., 221 F.3d 861, 865-66 (6th Cir. 2000)

${ }^{250}$ See, Dukane Precast, Inc., 25 OSHC (BNA) 1041 (A.L.J. July 14, 2014).

${ }^{251}$ See, Corrpro Companies, Inc., 24 OSHC (BNA) 1231 (A.L.J. Apr. 30, 2012)

${ }^{252}$ See, generally, Consol. Edison Co. of New York, 8 O.S.H. Cas. (BNA) 1550

(A.L.J. Apr. 17, 1980)
}

\section{Effective Rule Enforcement}

The employer must have a procedure that inspects for compliance of the work rules and a disciplinary procedure that punishes disobedience of the work rules. ${ }^{253}$ The timeliness of discovering the violation and reasonable diligence for checking on violations determine the adequacy of a procedure's enforcement of a work rule. ${ }^{254}$ As always, the daily internal inspections, the discovery of violations, and employee reprimanding can be documented in anticipation of future litigation. ${ }^{255}$ The employer can draft a plan for when an accident emerges because documented evidence of an employer's post-accident and postcitation activities are admissible before the Commission. $^{256}$ Properly implemented plans and procedures could help reduce the penalty or show the comprehensiveness and effectiveness of the work rule. ${ }^{257}$

\section{Isolated Incident Defense}

An employer may bolster its claim for Unpreventable Employee Misconduct by simultaneously claiming the Isolated Incident Defense. To prevail under the isolated incident defense, the employer must demonstrate that: (1) it took all feasible steps to prevent the accident; (2) the actions of its employees diverged from the effectively communicated and enforced work rule; and (3) the violation occurred without the knowledge or consent of the employer. ${ }^{258}$ The communication and enforcement of employer's safety rules are also preliminary requirements for this defense. ${ }^{259}$ The Secretary raises a detrimental rebuttal if it can show that a supervisor or higher title employee breached the work rule. ${ }^{260}$ The supervisor's lack of knowledge evidences inadequate communication and education of

\footnotetext{
${ }^{253}$ See, Pipeline Distrib. Contractors, Inc., 16 OSHC (BNA) 1293 (A.L.J. May 10, 1993); But see, Modern Continental Const. Co., Inc. v. OSHRC, 305 F.3d 43, 52 (1st Cir. 2002) (No record of noncompliance and no suspensions for repeat offenders caused the employer to fail on their Unpreventable Employee Misconduct claim.).

${ }^{254}$ See, A. Hansen Masonry, Inc., 19 O.S.H.C. 1041 (A.L.J. May 8, 2000); See Pike Co. Inc., 18 OSHC (BNA) - 1858 (A.L.J. June 21, 1999); See, Stark Excavation, Inc., 22 OSHC (BNA) 1455 (A.L.J. Nov. 18, 2008).

${ }^{255}$ See, Comtran Group, Inc., 23 OSHC (BNA) 2143 (O.S.H.R.C. Sept. 26 ,

${ }^{256}$ See, Prospect Waterproofing Co., 18 OSHC (BNA) 1340 (A.L.J. Oct. 15, 1997

${ }^{257}$ See, Brandenburg Indus. Services Co., 18 O.S.H. Cas. (BNA) ๆ 1386 (A.L.J. Apr. 6, 1998) ("A 25\% reduction [to the penalty was] applied for good faith in recognition of [an employer's] effective health and safety program on site."). See, Compass Envtl., Inc., 23 O.S.H. Cas. (BNA) 11132 (O.S.H.R.C. June 10, 2010) (Good faith reduction in penalty due to "an extensive safety program including (1) a disciplinary program; (2) safety audits; (3) written safety quizzes; (4) daily tailgate safety meetings; and (5) training for all of its other employees who worked at the job site."). The Commission is the "final arbiter of penalties." Brennan v. Occupational Safety \& Health Review Comm'n, 487 F.2d 438, 442 (8th Cir. 1973).

${ }^{258}$ See, Moseman Constr. Co., 12 OSHC (BNA) 『 1435 (A.L.J. July 1, 1985) (citing Daniel International, 683 F.2d 381 (11th Cir.1982)).

(citing
${ }^{259} I d$.
${ }^{260} \mathrm{See}$. $A$.

${ }^{250}$ See, Archer-W. Contractors, Ltd., 15 OSHC (BNA) $\mid 1013$ (O.S.H.R.C. Apr. 30, 1991).
} 
the work rule to tranches below her, and a supervisor's willful breach and assumption of the danger trivializes the work rule procedure. ${ }^{261}$ The employer may successfully argue an injury as being an isolated occurrence, but numerous supervisors ignoring internally constructed safety measures can make the work rule appear illusory to employees. ${ }^{262}$ When multiple employees engage in dangerous activity discordant with the internal safety policy, the Secretary can easily argue how the work rule is only "on paper" and not practically enforced. ${ }^{263}$ Therefore, numerous isolated violations could support the Secretary's contention that the employer failed to exercise reasonable diligence in enforcing the work rule and preventing an OSHA standard violation.

Courts use a frequency measurement to determine the effectiveness of a policy's enforcement: e.g., the number of the similar violations, the number of employees involved, and the number of discovered violations by supervisors. $^{264}$ The courts demand function over form. If an oral warning is sufficient to generate a nearly unblemished safety and health history, then the employer is effectively enforcing the work rule and the purpose of the General Duty Clause. $^{265}$ The Courts and the Secretary prefer to see an adaptation of the work rule, similar to how procedural adjustments are made in the law to correct administrative confusion or inefficiencies. Therefore, an employer's solemnness to its work rules is validated through a documented increase in the imposed penalty for each consecutive violation. ${ }^{266} \mathrm{~A}$ progressive discipline system is further discernible when supervisors are disciplined for personally violating work rules and for having an employee under their supervision violate a work rule or suffer an accident. ${ }^{267}$

\section{Greater Hazard Defense}

The General Hazard Defense offers employers the chance to disprove the success of OSHA standards at promoting a healthy and safe workplace. ${ }^{268} \mathrm{~A}$ court will presume the OSHA standard is effective as to preserve its value as a rule for uniform application. ${ }^{269}$ Employers must show that:

\footnotetext{
${ }^{261} I d$.

${ }^{262}$ See, Brock v. L.E. Myers Co., High Voltage Div., 818 F.2d 1270, 1277 (6th Cir. 1987)

${ }^{263}$ See, Westar Energy, 20 OSHC (BNA) ๆ 1736 (A.L.J. Feb. 17, 2004).

${ }^{264}$ See, Gem Indus., Inc., 17 OSHC (BNA) 1861 (O.S.H.R.C. 1996)

${ }^{265}$ See, Stark Excavating, Inc., 24 OSHC (BNA) 2218 (O.S.H.R.C. Nov. 3, 2014)

${ }^{266}$ See, also, S. K. Constr. Co., 16 OSHC (BNA) 1486 (A.L.J. Oct. 4, 1993).

${ }^{267}$ See, Westar Energy, 20 O.S.H. Cas. (BNA) 1736 (A.L.J. Feb. 17, 2004), p 10-11; See, Diamond Installations, Inc., OSHRC Docket No. 02-2080 \& 02-2081 (CMPAU Mar. 19, 2004), p 6.

${ }^{268}$ See, Caterpillar Inc. v. Herman, 131 F.3d 666, 669 (7th Cir. 1997)

${ }^{269} I$ d. at $668-69$.
}

compliance with OSHA standards or guidance would result in a greater hazard to employees, which the standard was designed to prevent, than would noncompliance;

(2) the employer took reasonable alternative protective measures, or there are no alternative means of employee protection; and

(3) a variance was unavailable or applying for a variance would have been inappropriate. ${ }^{270}$

When the OSHA standard or the OSH Act fails to abate the specific hazard it was designed to mitigate, the employer becomes responsible, under the General Duty Clause, to find an alternative way to prevent the unresolved recognized hazard. ${ }^{271}$ The employer must persuade the court, by a preponderance of the evidence, that all conceivable means of protecting the employee, the Secretary's prescribed safety standard, and any alternatives proposed by expert witnesses are unavailable. ${ }^{272}$ An employer must show the paucity of all conceivable protection methods when applied to its workplace. ${ }^{273}$ Seeking variance is appropriate, regardless of whether an employer fears exposing itself to a later citation or fears a low probability of acquiring variance. $^{274}$ The employer can apply for an interim order to prolong the possible issuance of a citation until a final decision is rendered on the variance application. ${ }^{275}$ The Commission views a variance request shortly before trial as a bad faith attempt to meet the variance element of the Greater Hazard Defense. ${ }^{276}$ The Secretary may outright deny the variance request once a citation has been issued regarding the matter. ${ }^{277}$ The purpose of requesting variance is to ensure the employer-prescribed alternative safety measure is as safe and healthful as the OSHA standard for addressing the specific hazard. ${ }^{278}$ Actual knowledge of the newly invented safety measure being inferior to the OSHA standard violates the General Duty Clause. ${ }^{279}$ Knowledge of the OSHA standard is a prerequisite to deciding whether the standard is unusable for the employer's particularized workplace; therefore, the Secretary can find the employer possessed actual knowledge of the OSHA

\footnotetext{
${ }^{270}$ OSHA Field Op Man. Sec VI, Ch. 5, S B(3) (D.O.L.); Dole v. Williams Enter. Inc., 876 F.2d 186,188 (D.C. Cir. 1989) (quoting Lauhoff Grain Co., 13 OSHC (BNA) 1084 (O.S.H.R.C. Feb. 4, 1987)) (emphasis added).

${ }^{271}$ See, Safeway, Inc. v. OSHRC, 382 F.3d 1189, 1194 (10th Cir. 2004).

${ }^{272}$ See, Dun-Par Engineered Form Co., 12 OSHC (BNA) ๆ 2053 (O.S.H.R.C. Sept. 3, 1986)

${ }^{273} I d$.

${ }^{274}$ See, Abf Freight System, Inc., Teamsters Loc. Union No. 988 Authorized Employee Rep., Docket No. 00-0737, (A.L.J. Dec. 26, 2000)

${ }^{275}$ See, 29 C.F.R. $\S 1905.11$ (c); 29 U.S.C. $\$ 655(\mathrm{~b})(6)(\mathrm{A})$ (regarding interim orders for temporary variance)

${ }^{276}$ See, Berkman Bros., Inc., 1992 OSHD (CCH) ๆ 29643 (A.L.J. Apr. 24, 1992)

${ }^{277}$ See, 29 C.F.R. $\$ 1905.5$.

${ }^{278}$ See, 29 U.S.C. § 655(d); See, AFL-CIO-CLC v. Marshall, 647 F.2d 1189 , 1268, (D.C. Cir. 1980)

${ }^{279}$ See, Gen. Elec. Co. v. Sec'y. of Labor, 576 F.2d 558, 561 (3d Cir. 1978).
} 
standard and the violation of the standard when establishing its initial burden of an OSH Act violation. ${ }^{280}$

The employer may relinquish the Greater Hazard Defense and, instead, issue an application for a variance with the Secretary to formalize its independently created safety standard. The Secretary's pre-approval of the alternative protection measure is accomplished through an order for a variance of the OSHA standard under 29 USC $\S 655(d)$. The variance application can be permanent or temporary. ${ }^{281}$ For temporary variance, an employer shall need to explain to the Secretary the conditions and method that shall provide an equivalent level of safety as the OSHA standard. ${ }^{282}$ The Secretary shall request a hearing and be given an opportunity to witness the alternative safety measure in-action. ${ }^{283}$ At the hearing, the Secretary evaluates whether more evidence exists supporting a finding that the employer's alternative processes would meet the same quality of healthfulness as the OSHA standard. ${ }^{284}$

To prevent a potential citation during a variance proceeding, the employer may apply for a temporary order to relieve the employer of compliance with the OSHA standard until the decision regarding the variance is rendered. ${ }^{285}$ Nevertheless, employers assuming they hold a superior and more efficient work rule may be uninformed about the Secretary's tested methods for providing safety to employees. The courts want the inappropriate private-sector methods to be stopped if shown through a variance that the methodology is insufficient to meet an OSHA standard's quality of safety. ${ }^{286}$ The employer remains in an inferior position because the employer voluntarily exposed himself to litigation and lost the Greater Hazard Defense. ${ }^{287}$ A work policy that exceeds the OSHA standard could succeed in litigation and a variance proceeding; however, the employer needs to determine the marginal cost of safety to the probability of a violation. At some point, the costs for additional safety substantially exceed the expected returns of preventing an unintentional violation.

\footnotetext{
${ }^{280}$ See, Sun Outdoor Advert., Inc., 5 OSHC (BNA) 1159 (O.S.H.R.C. Mar. 21, 1977) (Respondent knew of the presence of the violation in raising the Greater Hazard Defense). See, also, Modern Contl./Obayashi v. OSHRC, 196 F.3d 274, 279 (1st Cir. 1999)

${ }^{281}$ See, 29 U.S.C. $\$$ 655(b)(6), 655(d)

${ }^{282}$ See, 29 U.S.C. $\$$ 655(b)(6)(B), 655(d).

${ }^{283}$ See, 29 C.F.R. $\S 1905.11($ b)

${ }^{284}$ See, 29 U.S.C. $\$ 655($ d) (measured using "a preponderance of the evidence" standard); See, Adams Steel Erection, Inc., 12 OSHC (BNA) ๆ 1603 (A.L.J. Nov 25,1985 ) ("the Act carries with it a 'catch-22' or self-defeating result in that it requires a party seeking a variance to establish that it is not entitled to it. That is because, once it has been shown that compliance with the standard is more hazardous than non-compliance, the alternative method proposed to be used for a variance only has to be "as safe" as the standard — which was already determined to result in a greater hazard.").

${ }^{285}$ See, 29 C.F.R. $\S 1905.11(\mathrm{c})$.

${ }^{286}$ See, Gen. Elec. Co. v. Sec'y. of Labor, 576 F.2d 558, 561 (3d Cir. 1978).

${ }^{287}$ See, also, Barlament Erection Crane Rentals, 24 OSHC (BNA) 1777 (A.L.J. June 13, 2013).
}

However, the employer must seek a variance if attainable to avoid the courts from rejecting the employer's affirmation of the Greater Hazard Defense. ${ }^{288}$ An unjustifiable failure to seek a variance is fatal to raising the Greater Hazard Defense. ${ }^{289}$ If an OSH Act or state statute bars the application to seek variance, then the employer may wait until the citation emerges. ${ }^{290}$ For example, 29 U.S.C. $\S 655(b)(6)$ permits a variance from an OSHA standard, but a variance cannot be sought for a regulation. $^{291}$ The inability to obtain a variance proceeding can be documented and the statute or regulation barring variance can be monitored to ensure the inability to request variance remains the case before the violation unfortunately occurs. ${ }^{292}$ Furthermore, the Greater Hazard Defense succeeded when the hazard exposed itself for a task that lasted a short period of time and was performed on rare occasions: e.g., a 40-minute maintenance task that was performed only once every 15 years. $^{293}$ The irregularity of the task made seeking variance inappropriate when no hazard existed prior to performing the task. $^{294}$ This sporadic occurrence is distinct from the Isolated Incident Defense or Unpreventable Employee Misconduct Defense because the latter two defenses require an effectuated work rule to exist and the violation to occur without knowledge or consent.

\section{Conclusion}

This paper provides only a brief survey of the vast realm of the General Duty Clause defenses and the OSH Act. Supervisors and managers should seek legal counsel if they decide to appeal or litigate an OSH Act violation or apply for a variance. An employer knowledgeable of its rights can optimize its use of legal counsel because the employer can actively engage in discussing its situation. With a fundamental legal understanding, managers can also expand their critical-thinking when they can spot issues in their decisions that may lead to legal consequences.

\footnotetext{
${ }^{288}$ See, Caterpillar, Inc. v. Herman, 131 F.3d 666, 669 (7th Cir. 1997). See, J. E. Dunn Constr. Co., 21 O.S.H. Cas. (BNA) 1339 (A.L.J. Aug. 1, 2005) ("An employer cannot evade the variance requirement by stating that it knows it could not get one anyway.").

${ }^{289}$ Id. See, Barlament Erection Crane Rentals, 24 O.S.H. Cas. (BNA) ๆ 1777 (A.L.J. June 13, 2013). See, Gen. Elec. Co. v. Sec'y of Labor, 576 F.2d 558, 561 (3d Cir. 1978) (An employer cannot merely assert that its "working conditions are safer than those prescribed in the standards.").

${ }^{290}$ See, Caterpillar, Inc. v. Herman, 131 F.3d at 669; See, Glendon Energy Co. v. Borough of Glendon, 836 F.Supp. 1109, 1116 (E.D.Pa. 1993).

${ }^{291}$ See, Caterpillar Inc. v. Herman, 131 F.3d at 669

${ }^{292}$ See, e.g., Id

${ }^{293}$ See, Bethlehem Steel Corp., 10 OSHC (BNA) 『 1607 (O.S.H.R.C. Apr. 30, 1982)

${ }^{294}$ Id.
} 


\section{Funding Information}

This research did not receive any specific grant from funding agencies in the public, commercial, or not-forprofit sectors.

\section{Author Contributions}

Thomas Oriet: The legal research and principles.

Dr Leo Oriet: OSHA Health and Safety industrial practice.

\section{Ethics}

This paper is for informational purposes only and is not intended as an offer or solicitation for the sale of any legal product or service. It is not designed or intended to provide legal or other professional advice since such advice always requires consideration of an individual's circumstances. The validity of the law, cases, and legal principles mentioned in this paper may change after the publication date of this paper. If professional advice is needed, the services of a professional advisor should promptly be sought.

The pedagogical objective of this paper was to introduce the law and observe historically accepted and novel positions held in prior cases. Under the U.S. Constitution, U.S. citizens and companies have a due process right to pursue a meaningful opportunity to be heard through an appeal of the government's decision. The enforcement of these rights does not equate to an absolution of guilt or moral reprehensibility, which are circumstantial and idiosyncratic. Such moral questions exceed the scope of this paper.

\section{References}

5 U.S.C. $\S 556(d)$.

18 U.S.C. $\S 3282(\mathrm{a})$.

26 U.S.C. $\$ 652$.

26 U.S.C. $\$ 654$.

28 U.S.C. $\$ 1295$.

28 U.S.C. $\S 1391(b)(2)$.

29 C.F.R. $\S 1903.4$.

29 C.F.R. $§ 1903.6$.

29 C.F.R. $\$ 1903.7$.

29 C.F.R. $\S 1903.8$.

29 C.F.R. § 1903.17.

29 C.F.R. § 1903.20.

29 C.F.R. § 1926.28(A).

29 C.F.R. § 1905.10.

29 C.F.R. $\S 1905.11$.

29 U.S.C. $\S 651(b)$.

29 U.S.C. $§ 652(8)$.

29 U.S.C. $§ 653(4)$.
29 U.S.C. § 654.

29 U.S.C. $\$ 655$.

29 U.S.C. $\$ 657$.

29 U.S.C. $\$ 658$.

29 U.S.C. $\$ 659$.

29 U.S.C. $\$ 660$.

29 U.S.C. $\$ 666$.

29 U.S.C. $\S 667$.

59 A.L.R. Fed. 320, § 19.

Abf Freight System, Inc., Teamsters Loc. Union No. 988 Authorized Employee Rep., Docket No. 00-0737, (A.L.J. Dec. 26, 2000).

Ace Sheeting \& Repair Co. v. OSHRC, 555 F.2d 439 (5th Cir. 1977).

Ackermann Enterprises, Inc., 10 OSHC (BNA) 『 1709 (O.S.H.R.C. May 25, 1982).

Ackermann Enterprises, Inc., OSHRC Docket No. 804971, p 2 (A.L.J. Aug. 7, 1981).

Adams Steel Erection, Inc., 12 OSHC (BNA) ๆ 1603 (A.L.J. Nov. 25, 1985).

Adkins v. Children's Hosp., 261 U.S. 525 (1923).

Advanta USA, Inc. v. Chao, 350 F.3d 726 (8th Cir. 2003).

AFL-CIO-CLC v. Marshall, 647 F.2d 1189 (D.C. Cir. 1980).

Allis-Chalmers Corp. v. OSHRC, 542 F.2d 27 (7th Cir. 1976).

Am. Airlines, Inc., 9 OSHC (BNA) 91415 (A.L.J. Jan. 8, 1979).

American Petroleum Inst. v. Occupational Safety and Health Admin., 581 F.2d 493 (5th Cir. 1978).

American Textile Mfrs. Inst., Inc. v. Donovan, 452 U.S. 490 (1981).

American Textile Mfrs. Inst., Inc., 452 U.S. 490 (1981).

Anthony Crane Rental, Inc. v. Reich, 70 F.3d 1298 (D.C. Cir. 1995).

Antonin Scalia \& Bryan A. Garner, Reading Law (2012).

Archer-W. Contractors, Ltd., 15 OSHC (BNA) I 1013 (O.S.H.R.C. Apr. 30, 1991).

Archibeque v. Homrich, 543 P.2d 820 (N.M. 1975).

ASARCO, Inc. v. Occupational Safety and Health Admin., 746 F.2d 483 (9th Cir. 1984).

Atlantic \& Gulf Stevedores, Inc. v. OSHRC, 534 F.2d 541 (3d Cir. 1976).

Babcock \& Wilcox Co. v. OSHRC, 622 F.2d 1160 (3rd Cir. 1980).

Balsa U.S.A., Inc. v. Austin, 60 F. Supp. 2d 723 (W.D. Mich. 1999).

Bancker Const. Corp. v. Reich, 31 F.3d 32 (2nd Cir. 1994).

Barlament Erection Crane Rentals, 24 OSHC (BNA) 1777 (A.L.J. June 13, 2013).

Baroid Div. of NL Industries, Inc. v. OSHRC, 660 F.2d 439 (10th Cir. 1981).

Beaver Plant Operations, 18 OSHC (BNA) \& 1972 (O.S.H.R.C. Sept. 30, 1999). 
Bedal v. Hallack\& Howard Lumber Co., 226 F.2d 526 (9th Cir. 1955).

Berkman Bros., Inc., 1992 OSHD (CCH) ๆ 29643 (A.L.J. Apr. 24, 1992).

Bethlehem Steel Corp., 10 OSHC (BNA) ๆ 1607 (O.S.H.R.C. Apr. 30, 1982).

Boggs v. Boggs, 520 U.S. 833 (1997).

Boise Cascade Corp., Composite Can Div. v. Sec'y of Labor and OSHRC, 694 F.2d 584 (9th Cir. 1982).

Bowles v. Reade, 198 F.3d 752 (9th Cir. 1999).

Bragunier Masonry Contractors, Inc. v. Maryland Com'r of Labor and Indus., 684 A.2d 6 (Md. Spec. App. 1996).

Brandenburg Indus. Services Co., 18 O.S.H. Cas. (BNA) ๆ 1386 (A.L.J. Apr. 6, 1998).

Brandenburg Indus. Services Co., 18 O.S.H. Cas. (BNA) ब 1386 (A.L.J. Apr. 6, 1998).

Brennan v. Buckeye Indus., Inc., 374 F. Supp. 1350 (S.D. Ga. 1974).

Brennan v. Chicago Bridge \& Iron Co., 514 F.2d 1082 (7th Cir. 1975).

Brennan v. OSHRC, 487 F.2d 438 (8th Cir. 1973).

Brennan v. OSHRC, 501 F.2d 1196 (7th Cir. 1974).

Brock v. Dun-Par Engineered Form Co., 843 F.2d 1135 (8th Cir. 1988).

Brock v. L.E. Myers Co., High Voltage Div., 818 F.2d 1270 (6th Cir. 1987).

Buckeye Indus., Inc. v. Sec'y of Labor, OSHRC, 587 F.2d 231 (5th Cir. 1979).

Burkart Randall Div. of Textron v. Marshall, 625 F.2d 1313 (7th Cir. 1980).

Cain v. Bovis Lend Lease, Inc., 817 F. Supp. 2d 1251 (D. Or. 2011).

Camara v. Mun. Ct. of City and County of San Francisco, 387 U.S. 523 (1967).

Cape \& Vineyard Div. of the New Bedford Gas and Edison Light Co. v. OSHRC, 512 F.2d 1148 (1st Cir.1975).

Capital Elec. Line Builders of Kansas, Inc. v. Marshall, 678 F.2d 128 (10th Cir. 1982).

Carlisle Equip. Co. v. U.S. Sec'y of Labor and Occupational Safety, 24 F.3d 790 (6th Cir. 1994).

Caterpillar Inc. v. Herman, 131 F.3d 666 (7th Cir. 1997).

Champlin Petroleum Co. v. OSHRC, 593 F.2d 637 (5th Cir. 1979).

Charpentier v. Godsil, 937 F.2d 859 (3rd Cir. 1991).

CMC Elec., Inc. v. Occupational Safety and Health Admin., 221 F.3d 861 (6th Cir. 2000).

Cody-Zeigler, Inc., 19 OSHC (BNA) 1410 (O.S.H.R.C. May 09, 2001).

Colonnade Catering Corp. v. U.S., 397 U.S. 72 (1970).

Color Pigments Mfrs. Ass'n v. Occupational Safety \& Health Admin., 16 F.3d 1157 (11th Cir. 1994).

Compass Envtl., Inc., 23 O.S.H. Cas. (BNA) ๆ 1132 (O.S.H.R.C. June 10, 2010).

ComTran Group, Inc. v. U.S. Dept. of Labor, 722 F.3d 1304 (11th Cir. 2013).
ComTran Group, Inc., 23 OSHC (BNA) ף 2143 (O.S.H.R.C. Sept. 26, 2013).

Consol. Edison Co. of New York, 8 O.S.H. Cas. (BNA) ๆ 1550 (A.L.J. Apr. 17, 1980).

Consol.-Andy, Inc. v. Donovan, 642 F.2d 778 (5th Cir. 1981).

Contour Erection \& Siding Sys., Inc., 18 OSHC (BNA) 1423 (A.L.J. Aug. 1, 1997).

Corrpro Companies, Inc., 24 OSHC (BNA) q 1231 (A.L.J. Apr. 30, 2012).

Crane v. Conoco, Inc., 41 F.3d 547 (9th Cir. 1994).

Crowther Roofing \& Sheet Metal of Florida, 23 OSHC (BNA) 『 1361 (A.L.J. Oct. 15, 2010).

D.A. Collins Const. Co., Inc. v. Sec'y of Labor, 117 F.3d 691 (2nd Cir. 1997).

Danco Const. Co. v. OSHRC, 586 F.2d 1243 (8th Cir. 1978).

Daniel International v. OSHRC, 683 F.2d 381 (11th Cir.1982))

Diamond Installations, Inc., OSHRC Docket No. 022080 \& 02-2081 (CMPAU Mar. 19, 2004).

Dierzen-Kewanee Heavy Indus., Ltd., 22 OSHC (BNA) ๆ 1656 (A.L.J. Feb. 17, 2009).

Divesco Roofing and Insulation Co., 4 OSAHRC 339 (OSHRC 1973).

Dole v. Williams Enter. Inc., 876 F.2d 186 (D.C. Cir. 1989).

Donovan v. A.A. Beiro Const. Co., Inc., 746 F.2d 894 (D.C. Cir. 1984).

Donovan v. Adams Steel Erection, Inc., 766 F.2d 804 (3d Cir. 1985).

Donovan v. Fall River Foundry Co., 712 F.2d 1103 (7th Cir. 1983).

Donovan v. Federal Clearing Die Casting Co., 655 F.2d 793 (7th Cir. 1981).

Donovan v. General Motors Corp., 764 F.2d 32 (1st Cir. 1985).

Downrite Engr. Corp., 21 OSHC (BNA) 『 1536 (ALJ Feb. 6, 2006).

Dukane Precast, Inc., 25 OSHC (BNA) ๆ 1041 (A.L.J. July 14, 2014).

Dun-Par Engineered Form Co., 12 OSHC (BNA) ๆ 2053 (O.S.H.R.C. Sept. 3, 1986).

Dunlop v. Hertzler Enterprises, Inc., 418 F. Supp. 627 (D.N.M. 1976).

E \& R Erectors, Inc. v. Sec'y of Labor, 107 F.3d 157 (3rd Cir. 1997).

E \& R Erectors, Inc. v. Sec'y of Labor, 107 F.3d 157 (3rd Cir. 1997).

Electric Smith, Inc. v. Sec'y of Labor, 666 F.2d 1267 (9th Cir. 1982).

Ellis v. Chase Commc'ns, Inc., 63 F.3d 473 (6th Cir. 1995).

Empire-Detroit Steel Div., Detroit Steel Corp. v. OSHRC, 579 F.2d 378 (6th Cir. 1978).

Evans v. Eaton Corp. Long Term Disability Plan, 514 F.3d 315, 322 (4th Cir. 2008). 
F.D.I.C. v. Schuchmann, 235 F.3d 1217 (10th Cir. 2000).

Fabi Constr. Co. v. Sec'y of Labor, 508 F.3d 1077 (D.C. Cir. 2007).

Fair v. Mills, 230 F. Supp. 3d 1305 (M.D. Fla. 2017).

Fed. R. Civ. P. 15(b).

Fed. R. Civ. P. 8(c).

Fed. R. Civ. P., 16(b).

Figgs v. Bellevue Holding Co., 652 A.2d 1084 (Del. Super. 1994).

Florida v. Jimeno, 500 U.S. 248 (1991).

Foman v. Davis, 371 U.S. 178 (1962).

Frank Lill \& Son, Inc. v. Sec'y of Labor, 362 F.3d 840 (D.C. Cir. 2004).

Gade v. National Solid Wastes Management Ass'n, 505 U.S. 88 (1992).

Gem Indus., Inc., 17 OSHC (BNA) 『 1861 (O.S.H.R.C. 1996).

Gen. Elec. Co. v. Joiner, 522 U.S. 136 (1997).

Gen. Elec. Co. v. OSHRC, 540 F.2d 67 (2d Cir. 1976).

Gen. Elec. Co. v. Sec'y. of Labor, 576 F.2d 558 (3d Cir. 1978).

General Dynamics Corp. v. OSHRC, 599 F.2d 453 (1st Cir. 1979).

Glendon Energy Co. v. Borough of Glendon, 836 F. Supp. 1109 (E.D. Pa. 1993).

Greyhound Lines-West v. Marshall, 575 F.2d 759 (9th Cir. 1978).

Griggs v. Pace American Group, Inc., 170 F.3d 877 (9th Cir. 1999).

Grossman, 4 OSHC 1175, 1189 (BNA) (1976) OSAHRC LEXIS 528.

Hansen Masonry, Inc., 19 OSHC 1041 (A.L.J. May 8, 2000).

Harry C. Crooker \& Sons, Inc. v. OSHRC, 537 F.3d 79 (1st Cir. 2008).

Hills Materials Co. v. Rice, 982 F.2d 514 (Fed. Cir. 1992).

IBP, Inc. v. Herman, 144 F.3d 861 (D.C. Cir. 1998).

Indus. Union Dept., AFL-CIO v. Am. Petroleum Inst., 448 U.S. 607 (1980).

Intl. Union, United Auto., Aerospace and Agr. Implement Workers of Am. v. Gen. Dynamics Land Sys. Div., 815 F.2d 1570 (D.C. Cir. 1987).

IV. Federal Agency Recordkeeping and Reporting Requirements., OSHA Field Op Man. Sec IV, Ch. 13 (D.O.L.).

J. A. Jones Construction Co., 15 O.S.H. Cas. (BNA) 『 2201 (No. 87-2059, 1993).

J. E. Dunn Constr. Co., 21 O.S.H. Cas. (BNA) 『 1339 (A.L.J. Aug. 1, 2005).

J. F. White Contr. Co., 22 OSHC (BNA) 『 1917 (A.L.J. Sept. 08, 2009).

J. K. Butler Builders, Inc., 5 OSHC (BNA) ף 1075 (O.S.H.R.C. Feb. 25, 1977).

Jake's Fireworks, Inc., 26 O.S.H. Cas. (BNA) 『 1738 (A.L.J. Apr. 24, 2017).
James Everard's Breweries v. Day, 265 U.S. 545 (1924).

Jensen Constr. Co., 7 OSHC (BNA) 『 1477 (O.S.H.R.C. June 29, 1979).

Jones Oregon Stevedoring Co., Respondent I.L.W.U., Local 21, Authorized Employee Representative, 12 O.S.H. Cas. (BNA) ๆ 1778 (A.L.J. Feb. 4, 1986).

Keco Industries, Inc., 7 OSHC (BNA) 2048 (A.L.J. Dec. 27, 1978).

Keco Industries, Inc., 7 OSHC (BNA) ๆ 2048 (O.S.H.R.C. Dec. 19, 1979).

L. P. Kent Corp., 7 OSHC (BNA) ๆ 1030 (A.L.J. Nov. 13, 1978).

Lakeland Enters. of Rhinelander, Inc. v. Chao, 402 F.3d 739 (7th Cir. 2005).

Lauhoff Grain Co., 13 OSHC (BNA) ๆ 1084 (O.S.H.R.C. Feb. 4, 1987).

Linn v. U.S., 979 F. Supp. 521 (E.D. Ky. 1997).

Long Beach Container Terminal, Inc. v. OSHRC, 811 F.2d 477 (9th Cir. 1987).

Loomis Cabinet Co. v. OSHRC, 20 F.3d 938 (9th Cir. 1994).

M.C. Dean, Inc. v. Sec'y of Labor, 505 Fed. Appx. 929 (11th Cir. 2013) (unpublished).

Macias v. Cleaver, 1:13-CV-01819-BAM (E.D. Cal. Apr. 8, 2016).

Manson Constr. Co., 26 O.S.H. Cas. (BNA) 『 1568 (O.S.H.R.C. Apr. 27, 2017).

Marshall v. Barlow's, Inc., 436 U.S. 307 (1978).

Marshall v. Horn Seed Co., 647 F.2d 96 (10th Cir. 1981).

Marshall v. N. Am. Car Co., 626 F.2d 320 (3d Cir. 1980).

Marshall v. Weyerhaeuser Co., 456 F. Supp. 474 (D.N.J. 1978).

Martin v. Int'l Matex Tank Terminals-Bayonne, 928 F.2d 614 (3d Cir. 1991).

Matter of Trinity Industries, Inc., 876 F.2d 1485 (11th Cir. 1989).

Medina v. Catholic Health Initiatives, 877 F.3d 1213 (10th Cir. 2017).

Melerine v. Avondale Shipyards, Inc., 659 F.2d 706 (5th Cir. 1981).

Modern Continental Const. Co., Inc. v. OSHRC, 305 F.3d 43 (1st Cir. 2002).

Modern Contl./Obayashi v. OSHRC, 196 F.3d 274 (1st Cir. 1999).

Mohawk Excavating, Inc. v. OSHRC, 549 F.2d 859 (2nd Cir. 1977).

Moseman Constr. Co., 12 OSHC (BNA) 『 1435 (A.L.J. July 1, 1985).

Mounsey v. Ellard, 297 N.E.2d 43 (Mass. 1973).

Mountain States Tel. and Tel. Co. v. OSHRC, 623 F.2d 155 (10th Cir.1980).

N \& N Contractors, Inc. v. OSHRC, 255 F.3d 122 (4th Cir. 2001).

Nat'l Eng'g \& Contracting Co. v. Occupational Safety \& Health Admin., 928 F.2d 762 (6th Cir. 1991). 
Nat'l Mar. Safety Ass'n v. Occupational Safety \& Health Admin., 649 F.3d 743 (D.C. Cir. 2011).

Nat'l. Grain and Feed Ass'n v. Occupational Safety and Health Admin., 866 F.2d 717 (5th Cir. 1988).

Nat'1. Realty \& Const. Co., Inc. v. OSHRC, 489 F.2d 1257 (D.C. Cir. 1973).

Nelson v. Freeland, 349 N.C. 615 (1998).

North America's Building Trades Unions v. Occupational Safety \& Health Admin., 878 F.3d 271 (D.C. Cir. 2017).

O'Dell v. Hercules, Inc., 904 F.2d 1194 (8th Cir. 1990).

O'Neil v. Windshire Copeland Assoc., L.P., 197 F. Supp. 2d 507 (E.D. Va. 2002).

Occupational Safety and Health Admin., Employer Rights and Responsibilities Following a Federal OSHA Inspection, OSHA 3000-11R, 11 (2016), https://www.osha.gov/Publications/osha3000.pdf.

Ocean Elec. Corp. v. Sec'y of Labor, 594 F.2d 396 (4th Cir. 1979).

Oliver v. U.S., 466 U.S. 170 (1984).

OSHA Field Op Man. Sec VI (D.O.L.).

OSHA Field Op. Man. Sec III, Ch. 4(B)(6) (D.O.L.).

Overaa Const. v. California Occupational Safety and Health Appeals Bd., 54 Cal. Rptr. 3d 154 (Cal. App. 3d Dist. 2007).

P. Gioioso\& Sons, Inc. v. OSHRC, 675 F.3d 66 (1st Cir. 2012).

Pennsylvania Power \& Light Co. v. OHSRC, 737 F.2d 350 (3rd Cir. 1984).

People of California v. Kinder Morgan Energy Partners, L.P., 569 F. Supp. 2d 1073 (S.D. Cal. 2008).

Pike Co. Inc., 18 OSHC (BNA) ๆ 1858 (A.L.J. June 21, 1999).

Pipeline Distrib. Contractors, Inc., 16 OSHC (BNA) 1293 (A.L.J. May 10, 1993).

Pride Oil Well Serv., 15 O.S.H. Cas. (BNA) ๆ 1809 (O.S.H.R.C. Aug. 17, 1992).

Prima Facie Case, Black's Law Dictionary (10th ed. 2014).

Prospect Waterproofing Co., 18 OSHC (BNA) ๆ 1340 (A.L.J. Oct. 15, 1997).

Pullman Power Products, Inc. v. Marshall, 655 F.2d 41 (4th Cir. 1981).

Quinlan v. Sec'y, U.S. Dept. of Labor, 812 F.3d 832 (11th Cir. 2016).

REA Exp., Inc. v. Brennan, 495 F.2d 822 (1974).

Reich v. OSHRC, 102 F.3d 1200 (11th Cir. 1997).

Richmond Block, Inc., 6 OSHRC 180 (O.S.H.R.C. 1974).

Ries v. Nat'l R.R. Passenger Corp., 960 F.2d 1156 (3rd Cir. 1992).

Rockwell Intl. Corp., 17 OSHC (BNA) 『 1801 (O.S.H.R.C. Sept. 30, 1996).

S. K. Constr. Co., 16 OSHC (BNA) ๆ 1486 (A.L.J. Oct. 4, 1993).
S.A. Healy Co. v. OSHRC, 138 F.3d 686 (7th Cir. 1998).

S.E. Contractors, Inc., 8 OSHRC 285 (O.S.H.R.C. 1974) (overruled by S.E. Contractors, Inc v. Dunlop, 512 F.2d 675 (5th Cir. 1975)).

Safeway, Inc. v. OSHRC, 382 F.3d 1189 (10th Cir. 2004).

Salco Constr., Inc., 21 OSHC (BNA) 『 1662 (A.L.J. Apr. 24, 2006).

Sarasota Concrete Co., 9 OSHC (BNA) ๆ 1608 (Apr. 27, 1981).

SeaWorld of Fla., LLC v. Perez, 748 F.3d 1202 (D.C. Cir. 2014).

See v. City of Seattle, 387 U.S. 541 (1967).

Simplex Time Recorder Co. v. Secretary of Labor, 766 F.2d 575 (D.C. Cir. 1985).

Smith v. Arbaugh's Restaurant, Inc., 469 F.2d 97 (D.C. Cir. 1972).

Solis v. Summit Contractors, Inc., 558 F.3d 815 (8th Cir. 2009).

Southeast Contractors, Inc. v. Dunlop, 512 F.2d 675 (5th Cir.1975).

St. Joe Minerals Corp. v. OSHRC, 647 F.2d 840 (8th Cir. 1981).

Stark Excavating, Inc., 24 OSHC (BNA) - 2218 (O.S.H.R.C. Nov. 3, 2014)

Stark Excavation, Inc., 22 OSHC (BNA) ๆ 1455 (A.L.J. Nov. 18, 2008).

Steel Inst. of New York v. City of New York, 832 F. Supp. 2d 310 (S.D.N.Y.,2011).

Sun Outdoor Advert., Inc., 5 OSHC (BNA) ब 1159 (O.S.H.R.C. Mar. 21, 1977).

Talley v. Danek Med., Inc., 179 F.3d 154 (4th Cir. 1999).

Taylor Bldg. Associates, 5 OSHC (BNA) ๆ 1083 (O.S.H.R.C. Mar. 3, 1977).

Texas Indep. Ginners Ass'n v. Marshall, 630 F.2d 398 (5th Cir. 1980).

Thomas G. Gallagher, Inc. v. OSHRC, 877 F.3d 1 (1st Cir. 2017).

Tri-State Roofing \& Sheet Metal, Inc. v. OSHRC, 685 F.2d 878 (4th Cir. 1982).

Tri-State Steel Constr. Inc., 15 OSHC (BNA) \ 1903 (O.S.H.R.C. Sept. 30, 1992).

U.S. Const. Amend. IV.

U.S. Dept. of Labor, Multi-Employer Citation Policy OSHA Instructions CPL 02-00-124, (Dec. 10, 1999), https://www.osha.gov/pls/oshaweb/owadisp.show d ocument?p_table=DIRECTIVES\&p_id $=2024$.

U.S. Steel Corp. v. OSHRC, 537 F.2d 780 (3rd Cir. 1976).

U.S. v. Biswell, 406 U.S. 311 (1972).

U.S. v. Doig, 950 F.2d 411 (7th Cir. 1991).

U.S. v. Holloway, 290 F.3d 1331 (11th Cir. 2002).

U.S. v. Oliver, 686 F.2d 356 (6th Cir. 1982). 
Unifirst Corp., 2015 O.S.H. Dec. (CCH) ๆ 33423 (A.L.J. Oct. 17, 2014).

Universal Camera Corp. v. NLRB, 340 U.S. 474 (1951).

Universal Const. Co., Inc. v. OSHRC, 182 F.3d 726 (10th Cir. 1999).

Upshur Rural Elec. Coop. Corp., 7 O.S.H. Cas. (BNA) q 1573 (A.L.J. May 23, 1979).

Vanderwerf v. SmithKlineBeecham Corp., 414 F. Supp. 2d 1023 (D. Kan. 2006).

Victor Microwave, Inc., 17 OSHC. (BNA) ๆ 2141 (ALJ June 17, 1996).

Washlefske v. Winston, 234 F.3d 179 (4th Cir. 2000).
Wayne J. Griffin Electric, Inc., 26 BNA OSHC 1786 (No. 15-0858, 2017).

Weaver v. Palmer Bros. Co., 270 U.S. 402 (1926).

Webb v. Hodel, 878 F.2d 1252 (10th Cir. 1989).

Westar Energy, 20 OSHC (BNA) 1736 (A.L.J. Feb. 17, 2004).

Woods v. Carey, 722 F.3d 1177 (9th Cir. 2013).

World-Wide Volkswagen Corp v. Woodson, 444 U.S. 286 (1980).

Wye Elec., Inc., 18 O.S.H. Cas. (BNA) ๆ 1445 (A.L.J. May 26, 1998). 